Portland State University

PDXScholar

1983

\title{
The absence of extrachromosomal DNA in methanogenic bacteria
}

Nancy Ann Kurkinen

Portland State University

Follow this and additional works at: https://pdxscholar.library.pdx.edu/open_access_etds

Part of the Bacteria Commons, and the Biology Commons Let us know how access to this document benefits you.

Recommended Citation

Kurkinen, Nancy Ann, "The absence of extrachromosomal DNA in methanogenic bacteria" (1983). Dissertations and Theses. Paper 3352.

https://doi.org/10.15760/etd.5010

This Thesis is brought to you for free and open access. It has been accepted for inclusion in Dissertations and Theses by an authorized administrator of PDXScholar. Please contact us if we can make this document more accessible: pdxscholar@pdx.edu. 
AN ABSTRACT OF THE THESIS OF Nancy Ann Kurkinen for the Master of Science in Biology presented February 18, 1983.

Title: The Absence of Extrachromosomal DNA in Methanogenic Bacteria. APPROVED BY MEMBERS OF THE THESIS COMMITTEE:

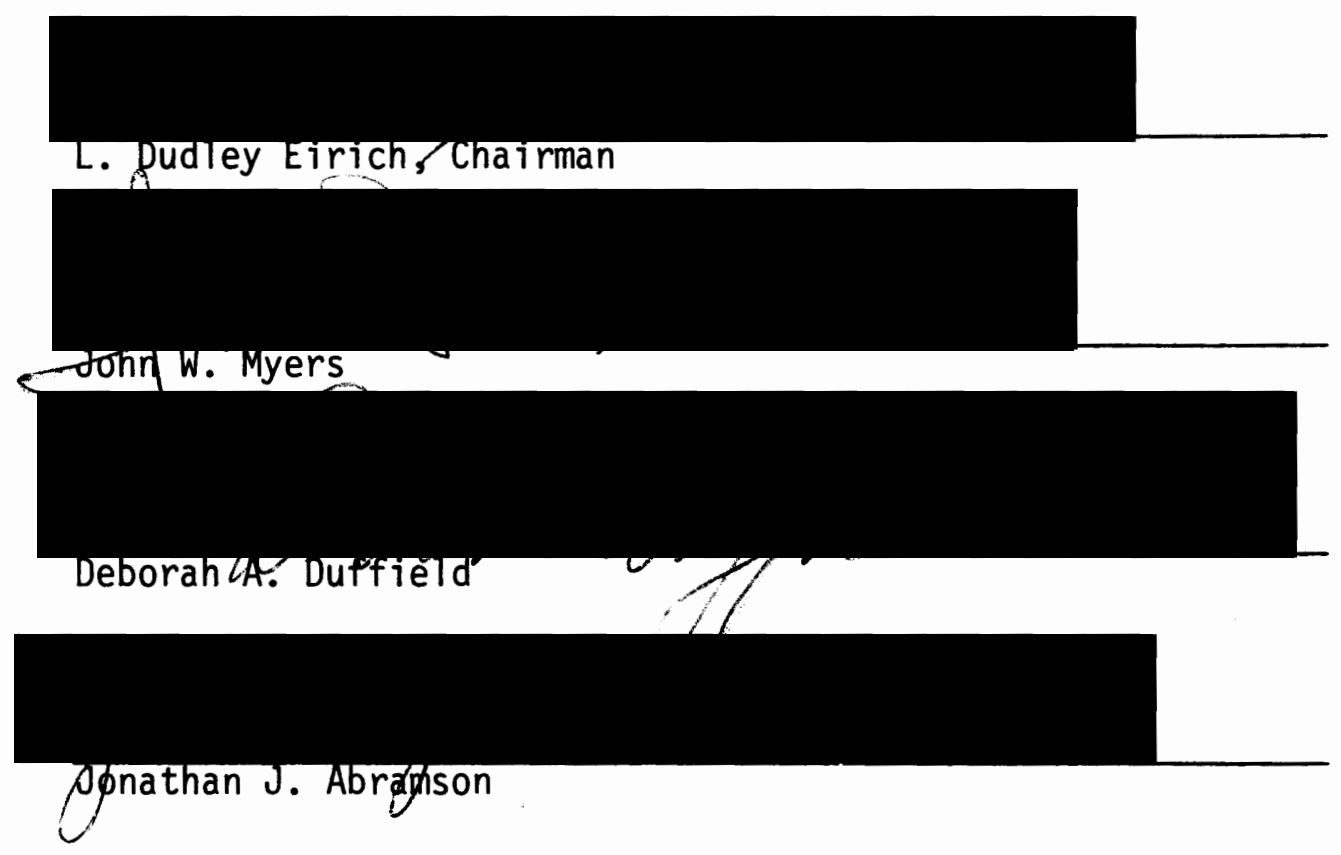

Abstract.

Five species of methanogenic bacteria were analyzed for the presence of plasmid DNA. Several procedures for the detection and isolation of covalently closed circular plasmid DNA were modified for use with the methanogens.

Electrophoretic analysis of DNA, isolated from Methanobacterium thermoautotrophicum, Methanobrevibacter species, Methanobrevibacter 
arboriphilus, Methanospirillum hungatii and Methanococcus voltae by one or more of the above techniques, showed no characteristic plasmid bands. Covalently closed circular DNA was not detected by cesium chloride ethidium bromide density gradient centrifugation of isolated DNA. Isopycnic centrifugation of whole cell lysates of Mc. voltae resolved only linear DNA.

A distinct but diffuse band resembling chromosomal DNA but of lower electrophoretic mobility was seen in all alkaline denatured preparations of Mc. voltae DNA. The electrophoretic mobility of this band relative to the mobilities of covalently closed circular and linear DNA indicates that it is not plasmid DNA.

The molecular character of the diffuse, nonchromosomal band from Mc. voltae was not verified. Results are presented which suggest that this DNA band, resolved from Mc. voltae, contains single stranded DNA in hairpin forms which arise by renaturation of inverted repeated sequences in the methanogenic genome. 
THE ABSENCE OF EXTRACHROMOSOMAL DNA

IN METHANOGENIC BACTERIA

by

NANCY ANN KURKINEN

A thesis submitted in partial fulfillment of the requirements for the degree of

\author{
MASTER OF SCIENCE \\ in \\ BIOLOGY
}

Portland State University

1983 
TO THE OFFICE OF GRADUATE STUDIES AND RESEARCH:

The members of the Committee approve the thesis of Nancy Ann Kurkinen presented February 18, 1983.

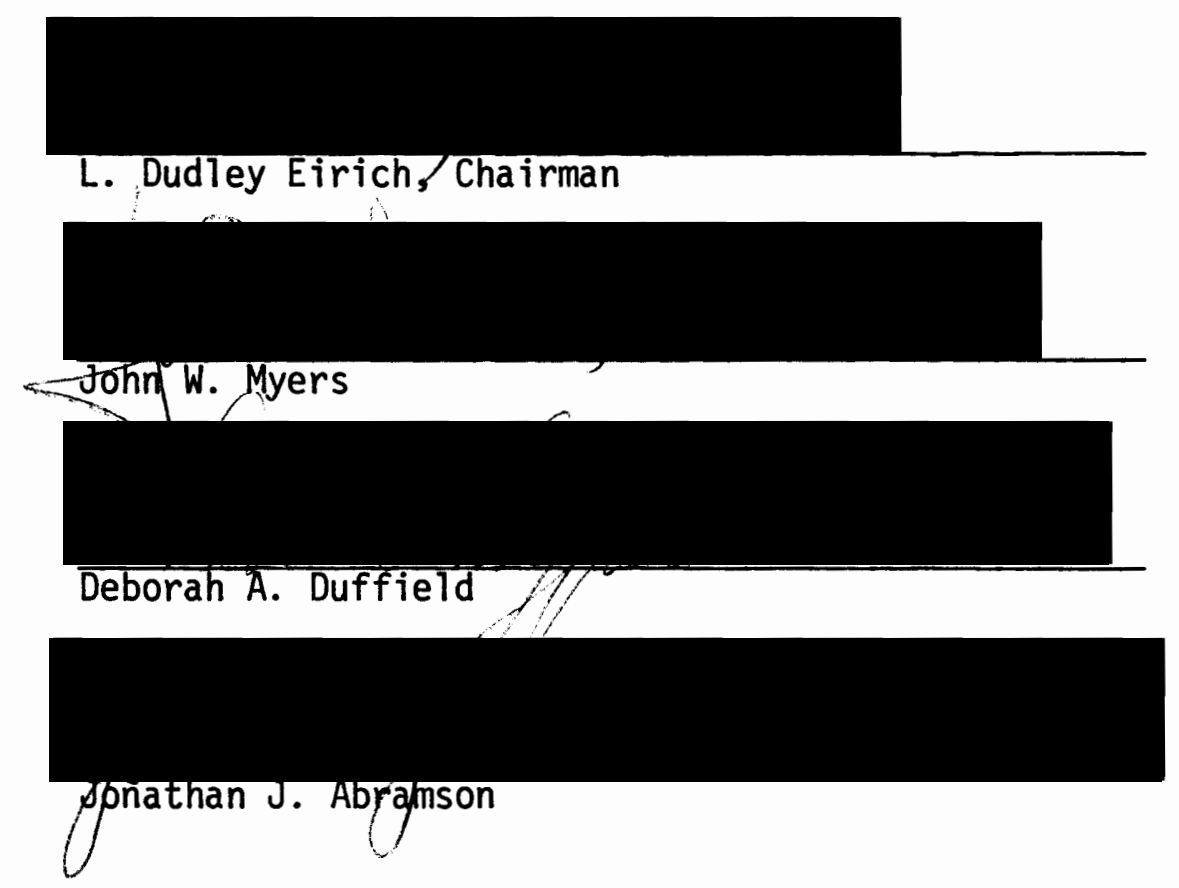

APPROVED:

W. Herman Faylor, Head, Departmenty of Biology

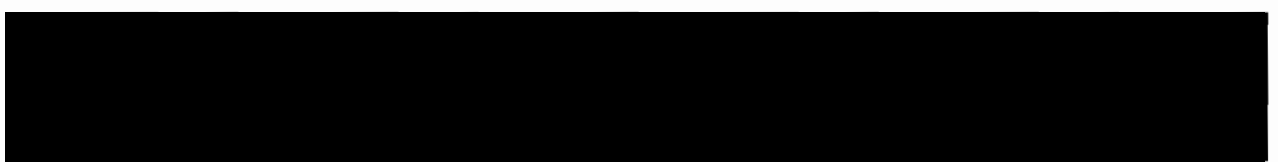

Stanley t. Rauch, Uean of Graduate studies and Research 


\section{ACKNOWLEDGEMENTS}

I wish to thank Dr. L. Dudley Eirich for his interest and support of my independent research project. As my advisor, he gave me an opportunity to experience first hand all aspects of scientific research.

I thank Dr. Jack Myers for daily conversation, consultation and technical assistance and Dr. Deborah Duffield for the moral support and encouragement with which she is so generous.

I am appreciative of the many hours each of my committee members shared with me, refining this manuscript.

I offer a special thank you to Rick for his patience and nagging.

This project was funded in part by a Research and Publications Award (\#90-050-5801-DEL) from the Office of Graduate Studies and Research, Portland State University. 
TABLE OF CONTENTS

PAGE

ACKNOWLEDGEMENTS.................................. i i

LIST OF TABLES.................................... vi

LIST OF FIGURES.................................. vii

INTRODUCTION........................................ 1

MATERIALS AND METHODS.................................. 4

Bacterial Strains.............................. 4

Chemicals..................................... 4

Growth and Culture of E. Coli $\ldots \ldots \ldots \ldots \ldots \ldots \ldots \ldots \ldots, 5$

Anaerobic Culture of the Methanogens................. 5

Media

Anaerobic Preparation of Media Growth

Isolation of Plasmid DNA......................... 7

Method I

Method II

Method III

Method IV

Method $V$

CsCl-EtBr Equilibrium Density Gradient Centrifugation

Detection of Plasmid DNA by Agarose Gel Electrophoresis....... 14

Electrophoresis of Isolated Plasmid DNA

Electrophoresis of Plasmid DNA following Lysis

in the Gel Slot 
RESULTS....................................... 16

Isolation and Detection of Plasmids................... 16

Methanobacterium and Methanobrevibacter

Methanospirillum

Methanococcus

Determination of the Character of the DNA Resolved

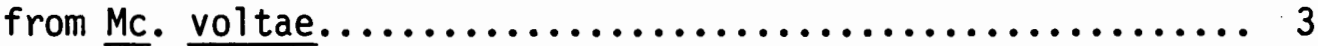

Relative Migration in Agarose Gels

Test for Nuclease Activity in Mc. voltae Lysates

The Effect of Alkaline Denaturation

Test for the Presence of Protein in the Trailing

Band from Mc. voltae

The Effect of Phenol Extraction 


\section{LIST OF TABLES}

TABLE

PAGE

I Techniques Employed with Test Organisms............ 8 


\section{LIST OF FIGURES}

FIGURE

PAGE

1. Agarose gel electrophoresis of $\underline{M}$. thermoautotrophicum

DNA prepared by Method I.................. 17

2. Agarose gel electrophoresis of $\underline{M}$. thermoautotrophicum and Methanobrevibacter sp. DNA prepared by

Method III........................... 21

3. Agarose gel electrophoresis of Mc. voltae DNA

prepared by Method IV.................... 25

4. Agarose gel electrophoresis of lysates of Mc. voltae

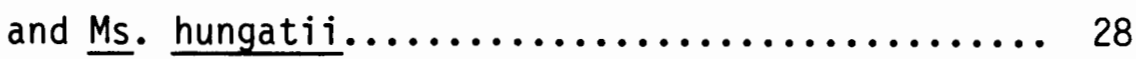

5. Agarose gel electrophoresis of lysates of Mc. voltae,

E. coli R45 and E. coli $517 \ldots \ldots \ldots \ldots \ldots \ldots \ldots . \ldots$

6. CsCl-EtBr equilibrium centrifugation of an Mc. voltae

lysate................................ 33

7. CsCl-EtBr equilibrium centrifugation of an $\underline{M c}$. voltae

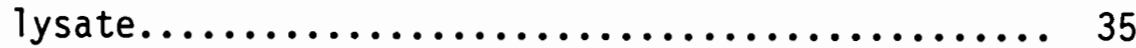

8. CsCl-EtBr equilibrium centrifugation of Mc. voltae

lysates prepared by heating.................. 37

9. $\mathrm{CsCl}-\mathrm{EtBr}$ equilibrium centrifugation of an $\mathrm{Mc}$. voltae

lysate prepared by stirring................ 40

10. Agarose gel electrophoresis of Mc. voltae DNA isolated

by $\mathrm{CsCl}-\mathrm{Etb}$ equilibrium centrifugation......... 42 
11. Comparative migration of DNA in $1.2 \%$ and $0.7 \%$ agarose of DNA isolated from Mc. voltae.............. 45

12. Comparative migration in $1.2 \%$ and $0.7 \%$ agarose of DNA from Mc. voltae lysates.

13. Agarose gel electrphoresis of plasmid DNA isolated

from a mixed culture of Mc. voltae and

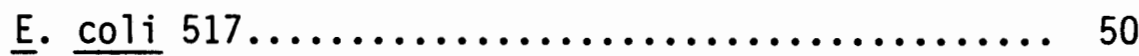

14. The effect of alkalinity......................... 53

15. Agarose gel electrophoresis of Mc. voltae DNA prepared with and without alkaline denaturation................................ 55 


\section{INTRODUCTION}

The methanogenic bacteria are a morphologically diverse group of strict anaerobes which have in common the ability to produce methane gas as an end product of their metabolism. Methanogens are commonly found in environments where organic material is being degraded: the rumen and intestinal tract of animals; sediments of aquatic habitats; sewage sludge digesters; municipal landfills. Methanogenesis allows complete fermentation of complex organic compounds in anaerobic environments. The end products of anaerobic degradation, hydrogen and carbon dioxide, are the major substrates for methane production.

Methanogens differ from other prokaryotes in cell wall and membrane structure as well as chemical and physiological characters (1). Recent studies comparing $16 \mathrm{~s}$, or eucaryotic $18 \mathrm{~s}$, ribosomal RNA oligonucleotide catalogs from a wide variety of bacteria and eukaryotic cell types $(2,3,4)$ show that methanogens belong to a phylogenetically distinct group of bacteria as unrelated to typical bacteria as they are to eukaryotic organisms. It has been proposed by woese et al. (5) that the methanogens, and the atypical halophilic and thermoacidophilic bacteria represent an ancient divergence in the evolution of prokaryotes: the primary kingdom, Archaebacteria. According to Woese, the archaebacteria, the eubacteria (all the prokaryotes except archaebacteria), and an urkaryote (the original eucaryotic cell), all stem from a common ancestor, the progenote: a cell much less 
sophisticated than any present day prokaryote. Woese speculates that in such a universal ancestor, the system for replication and expression of genetic information would be very crude. Cell lines diverging at this level of development would probably have independently evolved the highly specific enzymes and complex genetic apparatus we see in cells today.

To the extent that the methanogenic archaebacteria have been characterized, some components to the genetic processing system are different from those of the eubacteria. The DNA-dependent RNA polymerase isolated from $\underline{M}$. thermoautotrophicum differs from eubacterial RNA polymerases in size and subunit composition (6). Transfer RNA molecules from methanogens undergo post translational modification unlike that of modified eubacterial tRNA's (7). Histone like proteins isolated from three methanogenic species are serologically unrelated not only to eubacterial DNA binding proteins but to the histone like proteins from another archaebacterium, Thermoplasma (8).

Renaturation studies with DNA of $\underline{M}$. thermoautotrophicum (9) have shown the genome to be $40-50 \%$ the size of the $\underline{E}$. coli genome. Unlike the E. coli genome, 6 percent of the DNA from the methanogen was renatured at zero time indicating the possible frequent occurrence of inverted repeats in the genome. Genome complexity and homogeneity have not been determined for the other methanogenic species. DNA base composition varies among methanogenic genera from 27.5 to 61 mol percent guanine plus cytosine (4).

Gene expression and control have not been studied in the methanogens. Recent cloning experiments with Methanosarcina barkeri DNA, however, have demonstrated the expression of archaebacterial DNA in 
E. coli. (J. Koninsky, personal communication), suggesting that methanogens utilize the same genetic code as eubacteria; beyond this, however, nothing is known about the organization of genetic information in the methanogenic genome. Genetic exchange between methanogens has not been studied and extrachromosomal genetic elements have not yet been identified in the methanogens. Plasmids have been found in various strains of halophilic archaebacteria $(10,11)$.

Manipulation of plasmid DNA is widely used for the study of bacteria at the molecular level. The isolation of plasmid DNA from methanogenic bacteria would be the first step in the creation of a cloning vehicle that could be used for a wide variety of genetic and physiological studies. For example, the biochemistry of bacterial methanogenesis has not been determined: manipulation of the methanogenic genome is essential to the study of this system. As biological methanogenesis from organic waste materials could become a viable energy source, an understanding of the methanogenic genome, its expression and control will aid the development of energy related technologies.

The purpose of this project has been to initiate the study of methanogen genetics with a search for plasmid DNA in representative strains of methanogenic archaebacteria. 


\section{MATERIALS AND METHODS}

\section{BACTERIAL STRAINS}

Plasmid isolation procedures were performed on five methanogenic species. Methanobacterium thermoautotrophicum, Methanobrevibacter arboriphilus, Methanospirillum hungatii, and Methanococcus voltae were gifts from R. S. Wolfe, University of Illinois, Urbana. An uncharacterized Methanobrevibacter species was isolated from sewage sludge by Dr. L. D. Eirich, Portland State University.

Plasmid containing control stains were Escherichia coli strains 517 and R45. Escherichia coli 517 has 8 plasmids ranging in size from 1.4 Md to $36 \mathrm{Md}$ and was obtained from the Plasmid Reference Center, Stanford University. Escherichia coli R45 contains one 30 Md plasmid and was obtained from Ann Summers, University of Georgia.

\section{CHEMICALS}

Lysozyme, RNase A and protease were obtained from Sigma Chemical Co. The agarose used was Seakem ${ }^{R}$ (LE) Agarose obtained from Marine Colloids Division of FMC Corp. Cesium chloride was purchased from the Bethesda Research Laboratories, Inc. Loose phenol crystals from Mallinckrodt were liquified by heating. All other chemicals were of analytical grade and were purchased from various sources. 
GROWTH AND CULTURE OF E. COLI

Both E. coli strains were grown overnight in Luria broth [tryptone $(10 \mathrm{~g})$, yeast extract $(5 \mathrm{~g}), \mathrm{NaCl}(1 \mathrm{~g})$ and $\mathrm{K}_{2} \mathrm{HPO}_{4}(1 \mathrm{~g})$ per liter] at $37^{\circ} \mathrm{C}$ with shaking. Stock cultures of the $\underline{E}$. coli strains were maintained as stab cultures in vials of nutrient agar.

\section{ANAEROBIC CULTURE OF THE METHANOGENS}

The technique used in this study for routine growth of methanogens is that described by Balch et al. (4). The bacteria are cultured in sealed serum bottles in a pressurized atmosphere of $\mathrm{H}_{2}: \mathrm{CO}_{2}(80: 20 \mathrm{v} / \mathrm{v})$.

Media

The three media used are those described by Balch et al. (4). Methanobrevibacter sp., Mb. arboriphilus, and Ms. hungatii were grown in Medium 1, an enriched medium. $\underline{M}$. thermoautotrophicum was grown in a minimal medium, Medium 2. Mc. voltae was grown in high salt medium, Medium 3.

Anaerobic Preparation of Media

The preparation of these media was modified from Balch et al. as follows. The media were prepared without the reducing agents, cysteine and $\mathrm{Na}_{2} \mathrm{~S}$. They were not boiled under an atmosphere of $\mathrm{N}_{2}$ and $\mathrm{CO}_{2}$, but were simply added directly to the serum bottles in the presence of oxygen. The bottles were sealed and evacuated, causing the release of dissolved $\mathrm{O}_{2}$ from the media. The media were autoclaved for 15 minutes 
at $121^{\circ} \mathrm{C}$. Sterile media were stored at room temperature under a pressurized atmosphere of $\mathrm{H}_{2}: \mathrm{CO}_{2}(80: 20 \mathrm{v} / \mathrm{v})$.

The reducing agents were added to the media just before use. A sterile reducing solution ( $1 \%$ with respect to Cysteine- $\mathrm{HCl} \cdot \mathrm{H}_{2} \mathrm{O}$ and $\mathrm{Na}_{2} \mathrm{~S} \cdot 9 \mathrm{H}_{2} \mathrm{O}$ ) was prepared anaerobically as follows. A $1 \%$ cysteine solution ( $200 \mathrm{ml}$ in a $500 \mathrm{ml}$ flask) was neutralized by titration with $6 \mathrm{~N}$ $\mathrm{NaOH}$ and boiled over a flame. The flask was stoppered and transferred into a Freter-type anaerobic chamber (12). Solid $\mathrm{Na}_{2} \mathrm{~S}(0.5 \mathrm{~g})$ was dispensed to each of four, $100 \mathrm{ml}$ serum bottles. These bottles were sealed with stoppers and evacuated for transfer into the anaerobic chamber. Inside the chamber, the bottles were opened and $50 \mathrm{ml}$ of the cysteine solution was added to each. The bottles were resealed, capped with an aluminum crimp cap, transferred out of the chamber, and evacuated. The solution was autoclaved 10 minutes at $121^{\circ} \mathrm{C}$. Sterile reducing solution was stored at room temperature under an atmosphere of $\mathrm{N}_{2}$. The reducing solution was added to the culture media by sterile syringe $(1: 20 \mathrm{v} / \mathrm{v})$. The culture bottle was evacuated and then repressurized with $\mathrm{H}_{2}: \mathrm{CO}_{2}(80: 20 \mathrm{v} / \mathrm{v})$ to $30 \mathrm{psi}$. The media were allowed to stand until reduction was complete as indicated by the absence of any pink color conferred by oxidized resazurin in the media.

\section{Growth}

The culture bottles were pressurized to 30 psi with $\mathrm{H}_{2}: \mathrm{CO}_{2} \quad(80: 20$ $v / v)$ for incubation. Bottles were laid on their sides and shaken at 100 rpm in a rotary shaker. Methanobacterium thermoautotrophicum was incubated at $65^{\circ} \mathrm{C}$. All others were grown at $37^{\circ} \mathrm{C}$. During growth, the gas phase in each bottle was exchanged every 24-48 hours: methane, 
produced by the bacteria, was replaced with fresh substrate, $\mathrm{H}_{2}: \mathrm{CO}_{2}$ $(80: 20 \mathrm{v} / \mathrm{v})$.

Growth was crudely monitored by comparing the $\mathrm{H}_{2}: \mathrm{CH}_{4}$ ratio of the gas phase in the culture bottle. A $0.25 \mathrm{ml}$ gas sample was obtained with a sterile syringe which was flushed with $\mathrm{H}_{2}: \mathrm{CO}_{2}(80: 20 \mathrm{v} / \mathrm{v})$ before use. The sample was injected into a Varian Aerograph Model 90-P gas chromatograph using a Poropak $Q$ Column and $\mathrm{N}_{2}$ carrier gas for quantitative detection of $\mathrm{H}_{2}$ and $\mathrm{CH}_{4}$. Cell density was estimated during growth by relative optical density as measured with a Klett Summerson Photoelectric Colorimeter using a red filter. Culture samples were obtained from the bottles by sterile syringe and discarded after the reading.

Stock cultures of the methanogens were maintained by refrigeration in spent media under $\mathrm{H}_{2}: \mathrm{CO}_{2}(80: 20 \mathrm{v} / \mathrm{v})$ at 2 atmospheres pressure.

\section{ISOLATION OF PLASMID DNA}

Several published methods for the isolation of covalently closed circular (CCC) DNA were used in this study to examine the methanogens for the presence of plasmid DNA. Not all of these methods were performed on each bacterium. A summary of the techniques applied to the test organisms is presented in Table I, page 8. Each method was modified as described in the following sections, and additional modifications are noted with the results of specific preparations. Buffer solutions specific for each method are described with the 
TABLE I

TECHNIQUES EMPLOYED WITH TEST ORGANISMS

\begin{tabular}{|c|c|c|c|c|c|}
\hline & 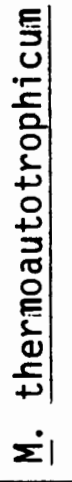 & 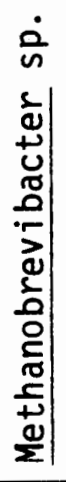 & 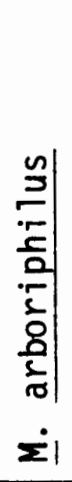 & 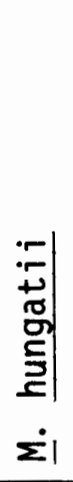 & 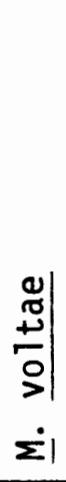 \\
\hline $\begin{array}{l}\text { Method 1. Alkaline denaturation, phenol } \\
\text { extraction }\end{array}$ & $\underline{x}$ & & & & $x$ \\
\hline $\begin{array}{l}\text { Method 11. Alkaline denaturation, } \mathrm{NaCl} \\
\text { precipitation, Phenol extraction }\end{array}$ & $x$ & $x$ & & & \\
\hline $\begin{array}{l}\text { Method III. Alkaline denaturation, } \mathrm{NaCl} \text { ppt., } \\
\text { PEC concentration }\end{array}$ & $\underline{x}$ & $\underline{x}$ & & $x$ & \\
\hline $\begin{array}{l}\text { Method IV. Alkaline denaturation, } \mathrm{NaA}_{c} \mathrm{ppt} ., \\
\text { ethanol concentration }\end{array}$ & $x$ & & $x$ & $x$ & $\underline{x}$ \\
\hline $\begin{array}{l}\text { Method V. Alkaline denaturation, } \mathrm{K} \text { ppt, } \\
\text { isoproponal concentration }\end{array}$ & $x$ & & $x$ & & $x$ \\
\hline $\begin{array}{l}\text { CsCl-EtBr Equilibrium Density Centrifugation } \\
\text { of Plasmid DNA isolated by alkine denaturation }\end{array}$ & $x$ & & $x$ & & $x$ \\
\hline $\begin{array}{l}\mathrm{CsCl-EtBr} \text { Equilibrium Density Centrifugation } \\
\text { of whole cell lysates }\end{array}$ & & & & & $\underline{x}$ \\
\hline Eckhardt Method & & & & $\underline{x}$ & $\underline{x}$ \\
\hline
\end{tabular}

$\underline{X}$ Photographic record of results are presented.

$X$ Photographic record of results are not presented. 
protocol. The following standard buffers were used throughout this work.

IE - $10 \mathrm{mM}$ Tris, $1 \mathrm{mM}$ EDTA, pH 8.0.

TES - $50 \mathrm{mM}$ Tris, $50 \mathrm{mM} \mathrm{NaCl}, 5 \mathrm{mM}$ EDTA, pH 8.0.

TERNase - $10 \mathrm{mM}$ Tris ( $\mathrm{pH} \mathrm{7.5),} 1 \mathrm{mM} \mathrm{Na}{ }_{3}$ EDTA, $10 \mathrm{mg} / \mathrm{ml}$ of RNase A. The solution was heated to $80^{\circ} \mathrm{C}$ for 20 minutes to remove contaminating DNases.

Method I - A Modification of the Method of Kado and Liu (13) $\frac{\text { Suspension Buffer }}{7.9 \text { with gTacial acetic acid. }} 40 \mathrm{mM}$ Tris-acetate, $2 \mathrm{mM} \mathrm{Na}{ }_{3}$ EDTA, adjusted to $\mathrm{pH}$

Lysing Solution - 3\% Sodium dodecyl sulfate (SDS), $50 \mathrm{mM}$ Tris adjusted to $\mathrm{pH} 12.6$ by addition of $1.6 \mathrm{ml}$ of fresh $2 \mathrm{~N} \mathrm{NaOH}$.

The bacteria were pelleted by centrifugation and the pellet placed at $-20^{\circ} \mathrm{C}$ until frozen. The cells were thawed by addition of $1.0 \mathrm{ml}$ of suspension buffer. Immediately upon thawing, $2 \mathrm{ml}$ of lysing solution were mixed with the cells by gentle inversion. The resultant lysate was transferred to a screw cap vial and incubated 15 minutes at $65^{\circ} \mathrm{C}$. Two volumes of phenol:chloroform $(50: 50 \mathrm{v} / \mathrm{v})$ were then added and the mixture emulsified by sharp inversions. Following centrifugation $(2,000 \times \mathrm{g}$ for 5 minutes at room temperature), the DNA-containing aqueous phase was removed by Pasteur pipette. A $0.2 \mathrm{ml}$ sample of the DNA solution was analyzed immediately by agarose gel electrophoresis. Two volumes of cold ethanol were added to the remaining solution and the DNA was allowed to precipitate overnight at $-20^{\circ} \mathrm{C}$. The precipitated DNA was recovered by centrifugation $\left(3,000 \times \mathrm{g}\right.$ for 10 minutes at $\left.4^{\circ} \mathrm{C}\right)$ and resuspended for electrophoretic analysis in $0.5 \mathrm{ml}$ TES buffer. 
Method II - A Modification of the Method of Casse et al.

Suspension Buffer - $50 \mathrm{mM}$ Tris, $20 \mathrm{mM}$ EDTA, pH 8.0.

Lysing Solution - $1 \%(w / v)$ SDS, $\mathrm{pH} 12.5$.

Bacteria were washed once in suspension buffer. The pellet was resuspended in 1 volume of lysing solution, and the suspension placed at $-20^{\circ} \mathrm{C}$ until frozen. Thawing was hastened by the addition of 5 volumes of lysing solution which was mixed with the cells by gentle inversion. The mixture was incubated at $37^{\circ} \mathrm{C}$ for 15 minutes and then the $\mathrm{pH}$ was lowered to 8.5 by addition of $2 \mathrm{M}$ Tris, $\mathrm{pH} 7.0$. The lysate was made $3 \%$ $\mathrm{NaCl}(\mathrm{w} / \mathrm{v})$ by the addition of solid $\mathrm{NaCl}$. After 15 minutes at room temperature, an equal volume of phenol:chloroform $(50: 50 \mathrm{v} / \mathrm{v})$ was added. The mixture was emulsified by sharp inversions and the phases separated by centrifugation $(2,000 \times \mathrm{g}$ rpm for 5 minutes $)$. The aqueous phase was removed by a Pasteur pipette. Two volumes of cold ethanol were added and the DNA was allowed to precipitate overnight at $-20^{\circ} \mathrm{C}$. The precipitated DNA was recovered and prepared for electrophoresis as described for Method I.

Method III - A Modification of the Method of Hansen and 01 sen

Suspension buffer - $50 \mathrm{mM}$ Tris, $20 \mathrm{mM}$ EDTA, DH 8.0

Lysing solution - 3\% SDS in Suspension buffer, $\mathrm{pH} 12.5$

Plasmid precipitating solution - $42 \%$ polyethylene glycol $(\mathrm{w} / \mathrm{v})$ in $0.01 \mathrm{M}$ sodium phosphate buffer, $\mathrm{pH} 7.0$.

The bacteria were resuspended in 1 volume of suspension buffer. Two volumes of lysing solution were added and mixed with the cells by gentle inversion of the tube. The $\mathrm{pH}$ of the suspension was adjusted to approximately 12.5 by the drop-wise addition of freshly prepared $3 \mathrm{~N}$ 
$\mathrm{NaOH}$. The cells were placed at $-20^{\circ} \mathrm{C}$ until frozen, thawed at room temperature and refrozen. A second thaw produced a slightly viscous lysate, the $\mathrm{pH}$ of which was lowered to approximately 9.0 by the addition of $2 M$ Tris, $\mathrm{pH} 7.0$. The lysate solution was made $3 \% \mathrm{NaCl}(\mathrm{w} / \mathrm{v})$ by the addition of solid $\mathrm{NaCl}$. The lysate was thoroughly mixed by gentle inversions and refrigerated $\left(4^{\circ} \mathrm{C}\right)$ for 6 hours. Precipitated chromosomal DNA was removed by centrifugation $\left(17,000 \times \mathrm{g}\right.$ for 20 minutes at $\left.4^{\circ} \mathrm{C}\right)$. The decanted supernatant was measured and $1 / 3$ volume of the plasmid precipitating solution was added for precipitation overnight at $4^{\circ} \mathrm{C}$. The DNA was recovered by centrifugation ( $900 \times \mathrm{g}$ for 5 minutes at $4^{\circ} \mathrm{C}$ ) and resuspended in $0.1 \mathrm{ml}$ TES buffer for electrophoretic analysis.

Method IV - A Modification of the Method of Birnboim and Doly (16)

Methanococcus voltae cells were found to lyse unless suspended in an isotonic solution. The following solutions were used on a test basis

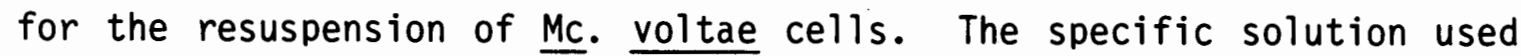
will be indicated with the results for each plasmid preparation. Sol I - $50 \mathrm{mM}$ glucose, $10 \mathrm{mM}$ EDTA, $25 \mathrm{mM}$ Tris-HCl (pH 8). 2\% Sol I - Sol I, made $2 \% \mathrm{NaCl}(\mathrm{w} / \mathrm{v})$ by the addition of solid $\mathrm{NaCl}$. $25 \%$ Sucrose

2\% TES - $50 \mathrm{mM}$ Tris, $5 \mathrm{mM}$ EDTA (pH 8), $2 \% \mathrm{NaCl}$

(The other methanogenic species were resuspended in Sol I.) Lysing Solution - $1 \%$ SDS and $0.2 \mathrm{~N} \mathrm{NaOH}$.

Five to ten volumes of bacterial culture were harvested by centrifugation and resuspended to 1 volume. Except where noted, the bacteria were lysed by adding 2 volumes of lysing solution and mixing it with the cells by gentle inversion. Unless otherwise noted, the 
thoroughly mixed lysates were neutralized within one minute after the lysing solution was added. The alkalinity of the lysate was varied by using a less alkaline SDS solution and adding differing amounts of $\mathrm{NaOH}$ to individual preparations. Such variations are noted in the Results.

The lysates were then neutralized by the addition of 1.5 'volumes of a $3 \mathrm{M}$ sodium-acetate solution, $\mathrm{pH} 4.8$. The contents of the tube were mixed by gentle inversion and the tube was maintained on ice for 1 hour. The heavy precipitate of DNA and protein was pelleted by centrifugation $\left(4,000-10,000 \times \mathrm{g}\right.$ at $4^{\circ} \mathrm{C}$ for 5 minutes $)$. Two volumes of cold ethanol were added to the supernatant and the DNA was allowed to precipitate overnight at $-20^{\circ} \mathrm{C}$. The precipitate was collected by centrifugation and resuspended in a $0.1 \mathrm{M}$ sodium-acetate solution ( $0.05 \mathrm{M}$ Tris-HCl, $\mathrm{pH} \mathrm{8.0)}$. After 30 minutes at $-20^{\circ} \mathrm{C}$, the precipitated DNA was recovered by centrifugation and resuspended in TERNase buffer.

Method V - A Modification of the Method of Birnboim and Doly.

A modification of the Birnboim and Doly technique, described elsewhere (17), was applied to Method IV as follows. An ice cold 5M potassium-acetate solution was substituted for 3M sodium-acetate. The neutralized lysate was allowed to stand on ice, 10 minutes before the precipitated chromosomal DNA and cell debris was collected by centrifugation $\left(12,000 \times \mathrm{g}\right.$, at $4^{\circ} \mathrm{C}$ for 20 minutes $)$. Six tenths of a volume of isopropanol was added to the supernatant which was then allowed to stand overnight at $-20^{\circ} \mathrm{C}$. Precipitated DNA was recovered by centrifugation $\left(12,000 \times \mathrm{g}\right.$ at $4^{\circ} \mathrm{C}$ for 10 minutes $)$. Pellets were washed with $70 \%$ ethanol and resuspended in TERNase buffer. 
CsCl-EtBr Equilibrium Density Gradient Centrifugation

Two methods for the isolation of plasmid DNA by isopycnic centrifugation were employed: 1.) DNA prepared by Method V was centrifuged as described by Maniatis (17, p. 93); 2.) Whole cell lysates of $\underline{\text { Mc. voltae }}$ were centrifuged by a modification of the method of Rosenberg (18). Rosenberg's technique was designed for the isolation of megaplasmids (300Md and greater). Cell lysis and subsequent mixing of the entire lysate with $\mathrm{CsCl}$ and ethidium bromide (EtBr) is performed as gently as possible to minimize shear forces, thus reducing fragmentation of the large molecules. Lysis conditions and preparations for centrifugation varied with each Mc. voltae experiment. Preparative details are described with the results of the individual centrifugations.

Al1 equilibrium centrifugations were performed with a Beckman Model L Preparative UItracentrifuge at $20^{\circ} \mathrm{C}$. Both a $\mathrm{Ti} 50$ rotor (tube capacity $13 \mathrm{ml}$ ), and a SW 65 rotor (tube capacity $5.5 \mathrm{ml}$ ) were used. Centrifugations were carried out for 48 hours at 35,000 rpm when using the SW 65 rotor and at 45,000 rpm for 36 hours with a Ti 50 rotor.

DNA bands were visualized with a hand held long wave UV light source (UVSL - 25 Mineral Light, Ultra Violet Products, Inc.). Centrifugation results were photographed using a Polaroid MP-4 land camera with a yellow filter. Polaroid Type 55 (Pos/Neg) film was exposed for times indicated.

DNA bands were collected from the polyalomer centrifuge tubes by needle (18 gauge) and syringe (17, p. 82). The EtBr was extracted from the DNA sample with isopropanol saturated with $5 \mathrm{M} \mathrm{NaCl}$. Following extraction, the EtBr free DNA solution was diluted with 2 volumes of 
water. Six volumes of cold ethanol were added and the DNA was allowed to precipitate overnight at $-20^{\circ} \mathrm{C}$. The DNA was collected by centrifugation $\left(12,000 \times \mathrm{g}\right.$ at $4^{\circ} \mathrm{C}$ for 10 minutes $)$ and resuspended in a minimal amount of TERNase buffer for analysis by agarose gel electrophoresis.

DETECTION OF PLASMID DNA BY

AGAROSE GEL ELECTROPHORESIS

All gel electrophoresis experiments were performed in Tris-acetate, E buffer ( $40 \mathrm{mM}$ Tris $-\mathrm{OH}, 20 \mathrm{mM}$ acetic acid, $2 \mathrm{mM} \mathrm{Na}{ }_{2}$ EDTA, $\mathrm{pH} 8.1$ ). All gels contained $0.8 \%$ agarose $(w / v)$ except where noted. The agarose was solubilized in $E$ buffer by heating the flask containing it over a flame. The agarose solution was allowed to boil gently with continuous swirling until a homogeneous solution was obtained. Gels were submerged in E buffer as soon as they solidified and the comb could be removed. These electrophoresis experiments were performed with a constant voltage power source. Specific voltages and running times are given with the results of each gel.

Gels were stained with $0.5 \mathrm{mg}$ of $\mathrm{EtBr}$ per $\mathrm{ml}$ for from 15-30 minutes. Background $\mathrm{EtBr}$ was removed by subsequent soaking of the gel in distilled $\mathrm{H}_{2} \mathrm{O}$ for from 15-30 minutes. DNA bands were visualized by illuminating the gel with long wave ultra-voilet light (Chromato-Vue ${ }^{R}$ Transilluminator, Ultraviolet Products, Inc.). Photographs were made with Polaroid Type 55 (Pos/Neg) or Type 57 (high speed) films, exposed through a yellow filter for times indicated. 
Electrophoresis of Isolated Plasmid DNAs

Electrophoresis of prepared DNA was performed using a horizontal slab gel apparatus (slab, $165 \mathrm{~mm} \times 143 \mathrm{~mm}$ ). Sample wells ( $5 \mathrm{~mm} \times 4 \mathrm{~mm} \times 2.5 \mathrm{~mm}$ ) were prepared with a teflon comb having 16 teeth. The DNA was mixed 4:1 ( $\mathrm{v} / \mathrm{v})$ with a loading buffer, $(25 \%$ sucrose and $0.125 \%$ bromphenol blue in TE buffer) and $10 \mu 1$ samples were applied to gel slots using a Gilson Pipetmen micropipetter. Each disposable tip was trimmed back $2 \mathrm{~mm}$ with a razor blade to make a larger orifice and thus reduce the shear forces on the DNA.

Electrophoresis of Plasmid DNA Following Lysis in the Gel Slot

Plasmid DNA from the $\underline{E}$. coli strains were analyzed using the detection procedure of Eckhardt (19). This method was modified slightly for use with the methanogenic strains as follows. A .05-0.5 ml culture aliquot was pelleted by centrifugation. The cells were resuspended in $15 \mu 1$ of a $20 \%$ Ficoll solution (E buffer, with $20 \%$ Ficoll 400 and $2 \%$ $\mathrm{NaCl}$ ). The suspended cells were added to $15 \mu 1$ of a dye solution (.05\% bromophenol blue in E buffer and 20\% Ficoll 400) and $30 \mu 1$ of an SDS solution ( $2 \%$ SDS in E buffer and $10 \%$ Ficoll 400) which were already mixed together in the well of an agarose gel. An overlay buffer $10.2 \%$ SDS in E buffer and 5\% Ficoll 400) was added to fill the well. This procedure was performed using both vertical agarose gels (as described by Eckhardt) and submerged horizontal agarose gels (as described above except with 8 well slots, $13 \mathrm{~mm} \times 5 \mathrm{~mm} \times 3 \mathrm{~mm})$. The vertical gels were $14 \mathrm{~mm} \times 10 \mathrm{~mm} \times 2 \mathrm{~mm}$ with 8 wells, $10 \mathrm{~mm} \times 13 \mathrm{~mm} \times 2 \mathrm{~mm}$. 


\section{RESULTS}

\section{ISOLATION AND DETECTION OF PLASMIDS}

Plasmid isolation techniques select for plasmid DNA on the basis of its covalently closed circular nature. The alkaline extraction methods preferentially denature and precipitate linear DNA. It has been demonstrated that within a narrow range of $\mathrm{pH}(12.0-12.5)$, linear DNA is denatured while CCC DNA is not (20). Denatured linear DNA can be separated from double stranded CCC DNA by precipitation at high salt concentrations (14).

DNA extracted from bacterial cells can be resolved by electrophoresis in agarose gels. Covalently closed circular plasmid DNA migrates as distinct narrow bands in agarose. The migration rate of plasmid DNA is inversely related to the logarithm of the plasmid mass up to $140 \mathrm{Md}$ (14). Plasmid multimers, nicked open circular plasmids, and irreversibly denatured plasmid forms also appear as discrete bands after electrophoresis: Each form has characteristic migration rates in agarose (21). Due to random strand breakage during isolation, linear chromosomal DNA fragments vary in size $\left(10^{7} \mathrm{Md}\right.$ and greater) and appear as a diffuse band after electrophoresis. In Figure 1 (as in all figures presented which illustrate agarose gel electrophoresis results), the chromosomal band is indicated by an arrow at the left. In this particular gel the chromosomal band does not appear very diffuse; a more typical chromosomal band is shown in Figure 3, lane A. Plasmid bands 
Figure 1. Agarose gel electrophores is of $\underline{M}$. thermoautotrophicum DNA prepared by Method I.

Lanes $A$ and $D$ contain the DNA standard prepared from E. coli 517. Lane $B$ contains $\underline{M}$. thermoautotrophicum DNA. Lane $C$ contains $\underline{M}$. thermoautotrophicum DNA prepared as described for Method I except that the frozen cell pellet was subject to grinding with alumina powder to ensure rupture of the cells. The resultant paste was washed with the suspension buffer. Alumina and cellular debris were collected by centrifugation and the lysing solution was then added to the supernatant. Electrophores is was performed at 100 volts for 3.5 hours. The position of chromosomal DNA is indicated by an arrow at the left. 


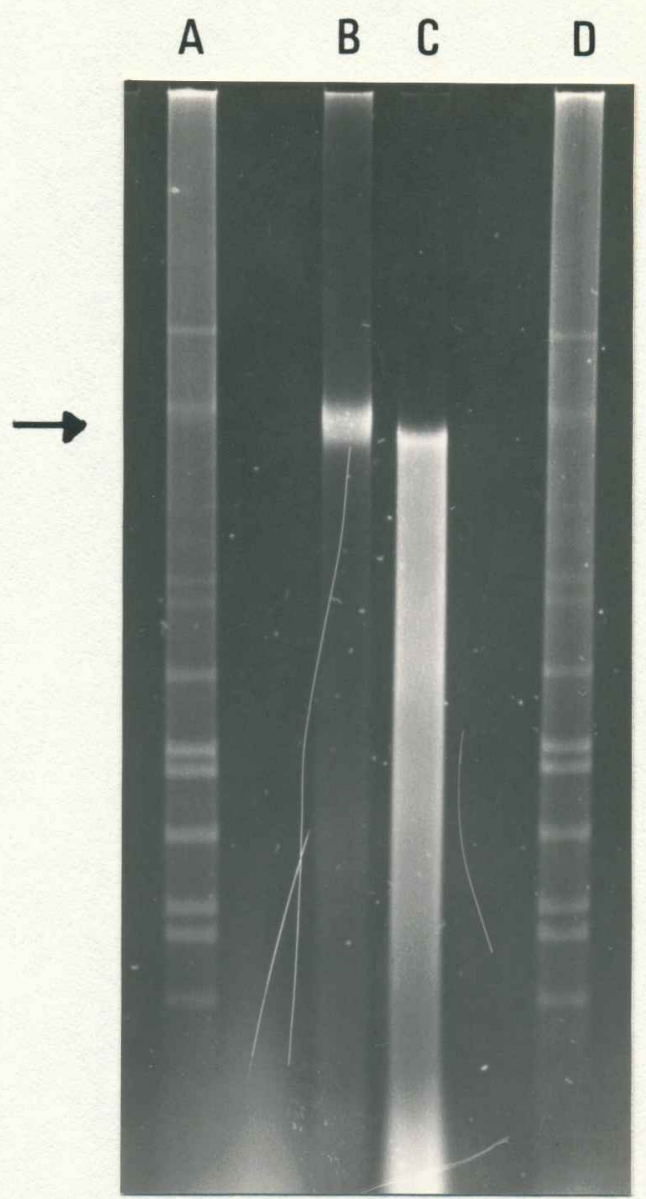

Figure 1 
are sharp because all the molecules which make up the band have the same molecular weight. The sharpness of the plasmid bands decreases with distance of travel. This phenomenon is shown in Figure 1.

Bacterial cells are lysed gently (dissolution of the bacterial envelope without use of mechanical forces) for the successful isolation of plasmid DNA. Most isolation techniques include lysis by SDS after dissolution of the cell walls with lysozyme. Lysozyme catalyzes hydrolysis of the B1-4 linkages in the polysaccharide chains of peptidoglycan. Since the cell walls of the methanogens do not contain peptidoglycan, alternative methods of gentle lysis were devised as indicated below for each individual genus. Cell lysis of the methanogens was determined microscopically, and by observing the viscosity of the suspension: DNA released from bacterial cells upon lysis increases the viscosity of the suspension dramatically.

Methanobacterium and Methanobrevibacter

Species of the genera Methanobacterium and Methanobrevibacter proved to be very resistant to gentle lysis. Attempts to lyse the cells by treatment with lysostaphin as prescribed for gram positive bacteria (22) were unsuccessful. Lysis with alkaline SDS solutions was also ineffective. Passage of these methanogens through a French Pressure Cell at 3,000 psi and lysis by grinding the cells with alumina powder produced viscous lysates; however, subsequent plasmid isolation by Methods I and III from these lysates produced a smear of fragmented linear DNA. The results obtained by Method I are shown in Figure 1, lane C. 
Effective, yet gentle, lysis was obtained by freezing and thawing the cells prior to addition of an alkaline SDS lysing solution. Methanobacterium thermoautorophicum DNA prepared by Method I following lysis by freezing and thawing the cells, resolved only chromosomal DNA as shown in Figure 1, lane B. DNA prepared from $\underline{M}$. thermoautotrophicum and Methanobrevibacter sp. following gentle lysis by freezing and thawing also resolved only chromosomal DNA.

Lysis by freezing and thawing was employed with Method III for isolation of plasmid DNA from $\underline{M}$. thermoautotrophicum and Methanobrevibacter sp. Unlike Methods I and II, this method does not include phenol extraction. As shown in Figure 2, the results obtained by Method III are different from those in Figure 1, obtained with Method I. By Method III, a very diffuse band is resolved from both preparations. The band from $\underline{M}$. thermoautotrophicum appears to be a composite of two diffuse bands. The mobility of the nearly distinct band at the top of the diffuse region did not correspond with the chromosomal band of the $\underline{E}$. coli 517 DNA standard. This distinct band was not seen in the Methanobrevibacter sp. DNA preparation. No characteristic plasmid bands were observed in any of these DNA preparations.

Methanobrevibacter arboriphilus cells, frozen and thawed in an alkaline SDS solution produced only moderate viscosity. Intact cells were observed microscopically in the lysate. The electrophoretic mobility of DNA prepared from such an Mb. arboriphilus lysate by Method III corresponded to that of chromosomal DNA (data not shown). When Mb. arboriphilus DNA is prepared by Method V, no chromosomal band is resolved; instead, a faint band similar to the non-chromosomal band 
Figure 2. Agarose gel electrophoresis of $\underline{M}$. thermoautotrophicum and Methanobrevibacter sp. DNA prepared by Method III.

Lane A contains the DNA standard prepared from E. coli 517 . Lane B contains $\underline{M}$. thermoautotrophicum DNA. Lane $\mathrm{C}$ contains Methanobrevibacter sp. DNA. Electrophoresis was performed at 100 volts for 5 hours. 


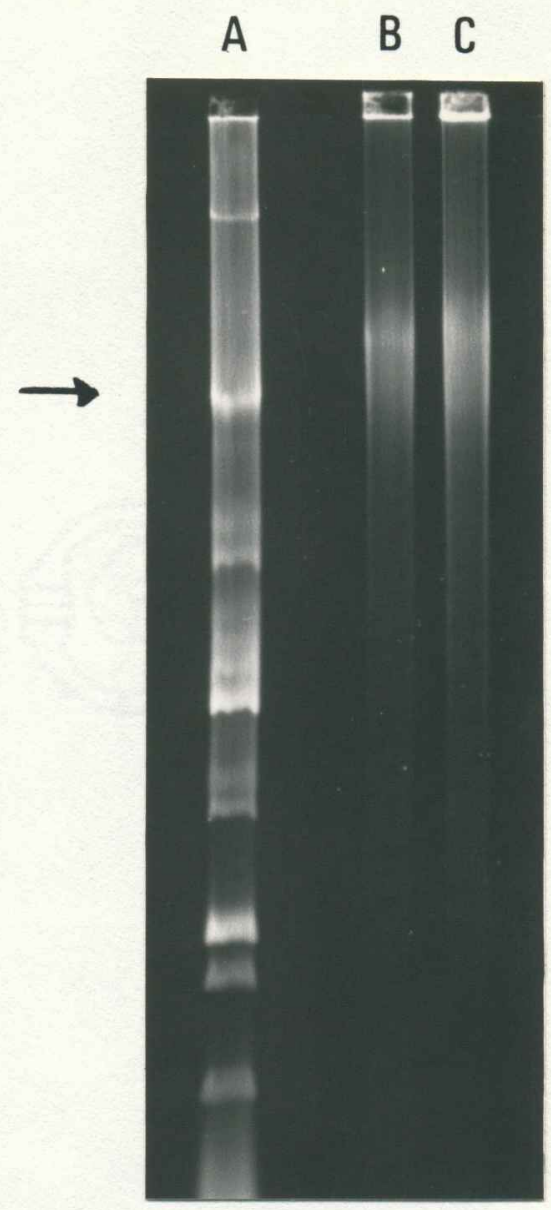

Figure 2 
resolved from $\underline{M}$. thermoautotrophicum is observed (data not shown).

DNA prepared from $\underline{M}$. thermoautotrophicum and $\underline{M b}$. arboriphilus by Method $V$ was analyzed by $\mathrm{CsCl}-\mathrm{EtBr}$ density gradient equilibrium centrifugation. No fluorescent bands were observed after centrifugation indicating an absence of CCC and linear DNA in the preparations (data not shown). In Method $V$, potassium-acetate is used to precipitate denatured chromosomal DNA and protein. The method is extremely efficient at removing chromosomal DNA. For comparison, the results of an equilibrium centrifugation of $\underline{E}$. coli 517 DNA prepared by Method $V$ are shown in Figure 8. The faint upper band is linear DNA. The intense lower band is CCC plasmid DNA.

Methanospirillum

The atypical cell wall of the genus Methanospirillum consists of a flexible inner wall surrounded by a rigid proteinaceous outer sheath $(23,24)$. This outer sheath is reportedly resistant to dissolution by SDS and alkali (24); however, complete lysis of Ms. hungatii cells was obtained with $0.65 \%$ SDS at pH 12 in the presence of EDTA as described for Method IV.

A single diffuse band corresponding to chromosomal DNA was resolved from Method IV preparations of Ms. hungatii DNA (data not shown). No characteristic plasmid bands were observed. A similar diffuse band was observed (see Figure 4) when Ms. hungatii DNA is analyzed electrophoretically following lysis of the bacterial cells directly in the wells of the agarose gels by the method of Eckhardt. This technique minimizes manipulation of the cell lysate, reducing the chance of damage to plasmid DNA. Megaplasmids with molecular weights of 
$400 \mathrm{Md}$ and possibly greater, have been resolved from Rhizobium meliloti and Pseudomonas solanacearum using this technique (18). Methanospirillum hungatii cells were suited for analysis by this method because they lyse readily in SDS solutions.

\section{Methanococcus}

Species of the genus Methanococcus are encased only in a single layer of protein subunits (4) and lyse readily in hypotonic solutions. Several isotonic solutions were used for resuspension of Mc. voltae cells. A solution of $2 \% \mathrm{NaCl}$ was found the most reliable for preventing premature lysis. The cells could then be lysed osmotically by the addition of a hypotonic solution. In some preparations, lysis was completed by the addition of Sarkosyl or SDS.

Electrophoretic analysis of DNA prepared from Mc. voltae by Method IV gave the varied results shown in Figure 3 . Lane $D$ represents the most common result: two diffuse bands of roughly equal intensity, one migrating at the same rate as the linear chromosomal DNA standard and a more slowly migrating band clearly distinct from the first. The broad diffuse band seen in lanes $E$ and $F$ is similar in appearance and migration to the diffuse band obtained from Methanobrevibacter sp. (see Figure 2). The migration of the two bands in lane $B$ is the same as that in lane D; but both bands in lane B appear much sharper and the chromosomal band is at least twice as concentrated as the slower band. In lanes $A$ and $C$, we see only the slower band. Although there is some fluorescence at the chromosomal position, a distinct band is not present in lanes $A$ and $C$. Characteristic plasmid bands were not resolved in any of the Mc. voltae preparations. As described in the legend of Figure 3, 
Figure 3. Agarose gel electrophoresis of Mc. voltae DNA prepared by Method IV.

Mc. voltae DNA was prepared as described for Method IV with specific modifications that follow. The DNA in lane $A$ was prepared from a $20 \mathrm{ml}$ culture resuspended in $25 \%$ sucrose $(2 \mathrm{ml})$. The $\mathrm{pH}$ of the lysing solution was 12.0 . The $\mathrm{pH}$ of the lysate was raised by the addition of $335 \mu 1$ of $2 \mathrm{~N} \mathrm{NaOH}$. The DNA in lane B was prepared from a $20 \mathrm{ml}$ culture resuspended in $25 \%$ sucrose $(2 \mathrm{ml})$. The $\mathrm{pH}$ of the lysing solution was 12.0. The $\mathrm{pH}$ of the lysate was raised by the addition of $280 \mu 1$ of $2 \mathrm{~N} \mathrm{NaOH}$. The DNA in lane $C$ was prepared from a $30 \mathrm{ml}$ culture resuspended in $25 \%$ sucrose $(3 \mathrm{ml})$. Prior to the addition of lysing

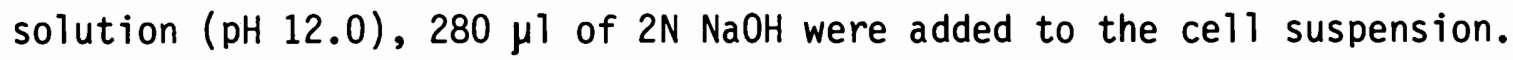
The DNA in lane $D$ was prepared from a $100 \mathrm{ml}$ culture resuspended in $2 \%$ Sol I $(5 \mathrm{ml})$. The DNA in lanes $E$ and $F$ were prepared from $25 \mathrm{ml}$ cultures resuspended in Sol I $(2 \mathrm{ml})$. Only one volume of lysing solution was added during preparation of the DNA in lane $F$. The unmarked lanes are the DNA standard prepared from E. coli 517. 


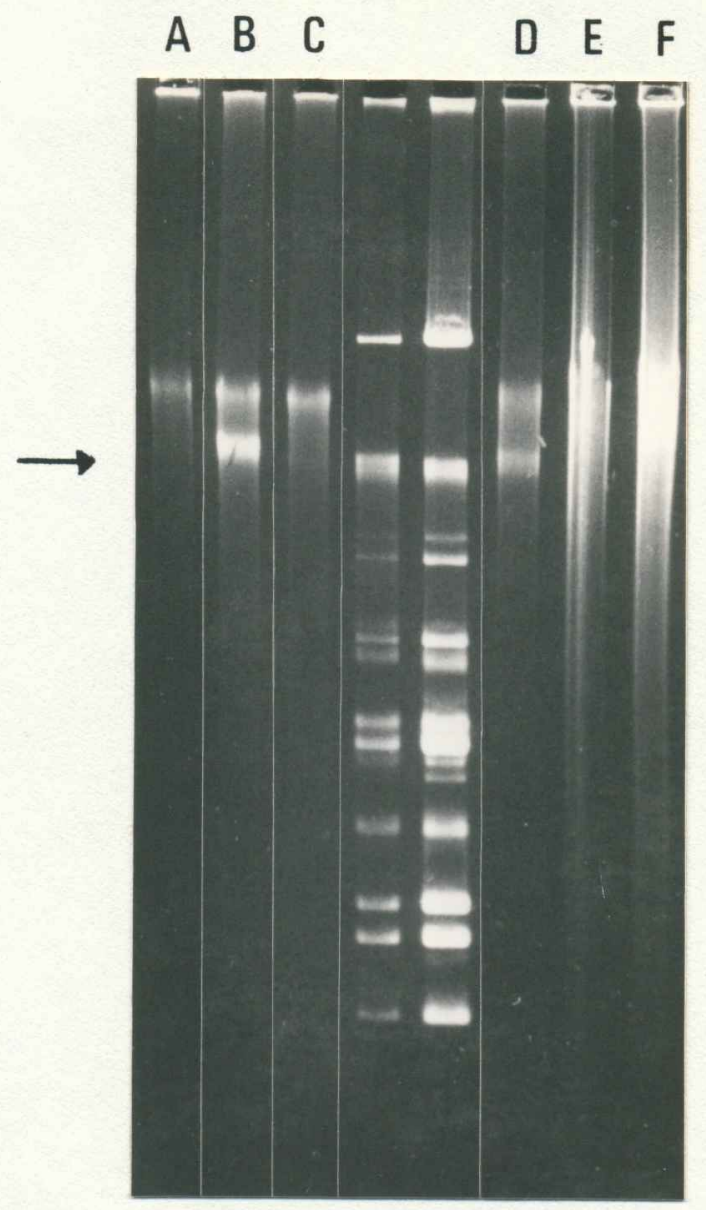

Figure 3 


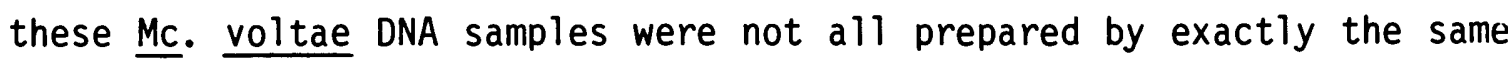
procedures. A reason for these varied results was investigated (see The Effect of Alkaline Denaturation).

DNA from Mc. voltae was analyzed electrophoretically following lysis of the cells directly in the wells of agarose gels as described for the Eckhardt procedure. Figure 4 shows the first results obtained by the detection method. A distinct plasmid like band appears near the gel slot in lane $D$ which contains an Mc. voltae lysate. Also in lane D, a band is seen trailing behind the chromosomal band and nearly obscured by it. This plasmid detection technique was repeated several times in an attempt to move the high molecular weight band (the band near the gel slot) farther away from the gel slot to eliminate the possibility that what was observed was an aberration of the slot due to the cellular debris it contained. The band was observed $2.5 \mathrm{~mm}, 2.5 \mathrm{~mm}, 3 \mathrm{~mm}, 3 \mathrm{~mm}$, and $4 \mathrm{~mm}$ from the leading edge of the slot as migration time was increased. With further experimentation, the high molecular weight band was not observed; although the band trailing the chromosomal band was still quite evident as shown in Figure 5. The reason for the disappearance of the high molecular weight band was not evident.

To determine whether either of the bands resolved from Mc. voltae by the Eckhardt method represented plasmids, Mc. voltae lysates were subjected to $\mathrm{CsCl}-\mathrm{EtBr}$ equilibrium density gradient centrifugation. Centrifugation of whole cell lysates was desirable for minimal manipulation of the DNA. While a plasmid of the extremely large size seen in Figure 4 (lane $D$ ) would probably be broken during preparation for centrifugation, the plasmid band observed trailing the chromosomal 
Figure 4. Agarose gel electrophoresis of lysates of Mc. voltae and Ms. hungatii.

Lysates were prepared as described for the Eckhardt procedure. Lanes A and B contain $0.2 \mathrm{ml}$ of E. coli 517 culture. Lane C contains $0.2 \mathrm{ml}$ of Ms. hungatij culture. Lane $\mathrm{D}$ contains $0.2 \mathrm{ml}$ of Mc. voltae culture. Electrophoresis was for one hour at 50 volts and then three hours at 120 volts. 


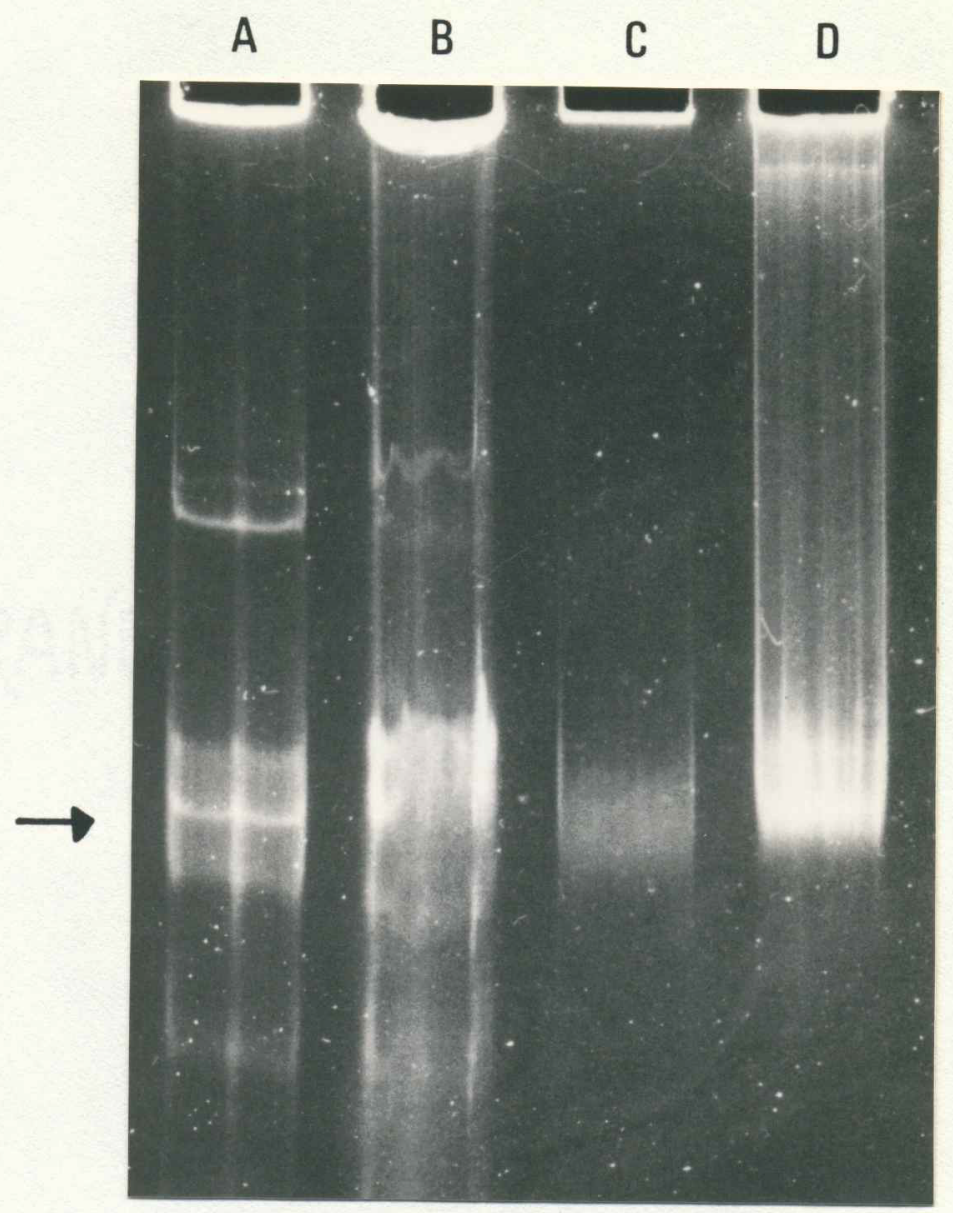

Figure 4 
Figure 5. Agarose gel electrophores is of lysates of Mc. voltae, E. coli R45 and E. coli 517.

Lysates were prepared as described for the Eckhardt procedure. Lanes A, B, C and D contain $0.4 \mathrm{ml}, 0.3 \mathrm{ml}, 0.2 \mathrm{ml}$ and $0.2 \mathrm{ml}$ of M. voltae culture, respectively. Lanes $E$ and $F$ contain $0.1 \mathrm{ml}$ and 0.2 $\mathrm{ml}$ of E. coli R45 culture, respectively. Lanes $G$ and $H$ contain $0.1 \mathrm{ml}$ and $0.2 \mathrm{ml}$ of E. coli 517 culture, respectively. Electrophores is was for one hour at 25 volts and then 5 hours at 100 volts in a $0.7 \%$ horizontal agarose gel. 


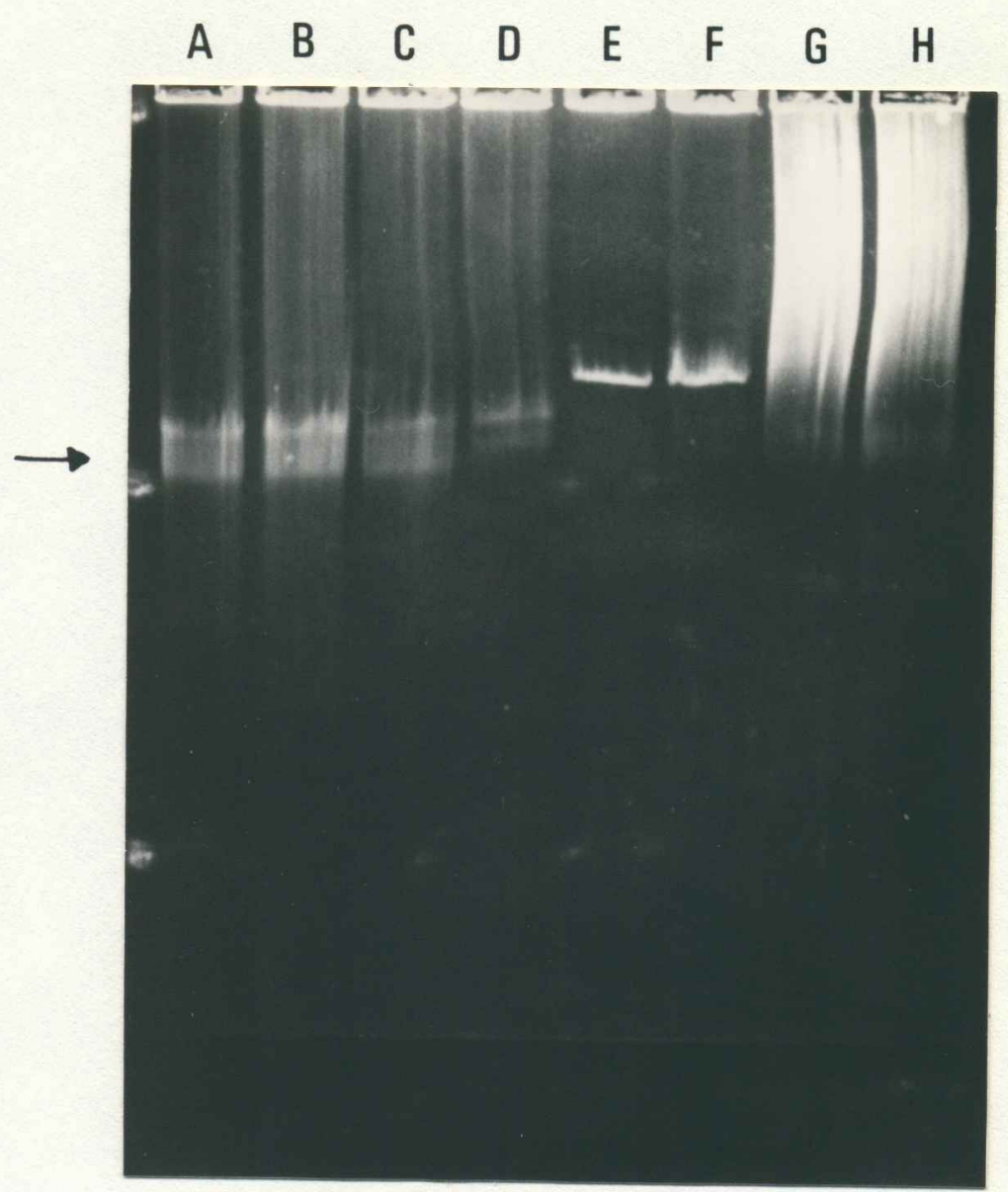

Figure 5 
band would represent CCC DNA of less than $36 \mathrm{Md}$ : Plasmids of this size are routinely isolated by $\mathrm{CsCl}-\mathrm{EtBr}$ centrifugation. Lysates of Mc. voltae were prepared for centrifugation as described for the Rosenberg method.

The result of the first lysate centrifugation is shown in Figure 6. Only one fluorescent band appeared. Since linear chromosomal DNA would be the major DNA component in a whole cell lysate, this band was assumed to be linear chromosomal DNA. The faintness of this band suggests that plasmid DNA could be present but at a concentration too low to detect. To investigate this, whole lysate centrifugations were repeated using higher cell concentrations. DNA bands were not resolved. Instead, a viscous fluorescent clot was repeatedly obtained (see Figure 7) precluding any further centrifugation attempts. These results seemed to be due to an inability to mix the extremely viscous lysates of Mc. voltae with the $\mathrm{CsCl}$ solution and not due to the increased cell concentration, as clots were obtained when the cell concentration was reduced to that used for the centrifugation shown in Figure 6 . It is not known why the first centrifugation experiment did not result in a clot also, as that lysate did not mix with the $\mathrm{CsCl}$ solution either. The use of a $\mathrm{CsCl}$ solution was discontinued.

Attempts to dissolve solid $\mathrm{CsCl}$ directly into the viscous lysates with mixing by gentle inversion were also unsuccessful: vigorous, continuous stirring with a glass rod was required. Solid $\mathrm{CsCl}$ dissolved readily into Mc. voltae lysates which were heated (see details in the legend of Figure 8 ) to reduce their viscosity. A single DNA band was observed (see Figure 8 ) after equilibrium centrifugation of the heated lysates. The density of this band appears to be less than that of the 
Figure 6. CsCl-EtBr equilibrium centrifugation of an Mc. voltae lysate.

A $25 \mathrm{ml}$ culture of $\underline{M c}$. voltae was resuspended in $0.2 \mathrm{ml}$ of $2 \%$ TES buffer (Method IV). One $\mathrm{ml}$ of TE buffer was added to the cells to induce osmotic lysis. The lysate was gently poured on top of $3.8 \mathrm{ml}$ of $\mathrm{CsCl}$ dissolved in $2.6 \mathrm{ml}$ of TE buffer in a $5.5 \mathrm{ml}$ polyalomer centrifuge tube. Four tenths of a $\mathrm{ml}$ of an $\mathrm{EtBr}$ solution $(10 \mathrm{mg} / \mathrm{ml})$ was added. Mixing by gentle inversion failed to combine the EtBr or the thick lysate with the $\mathrm{CsCl}$ solution. The details of centrifugation and photography are described in Materials and Methods. Polaroid Type 55 film was exposed 10 minutes. 


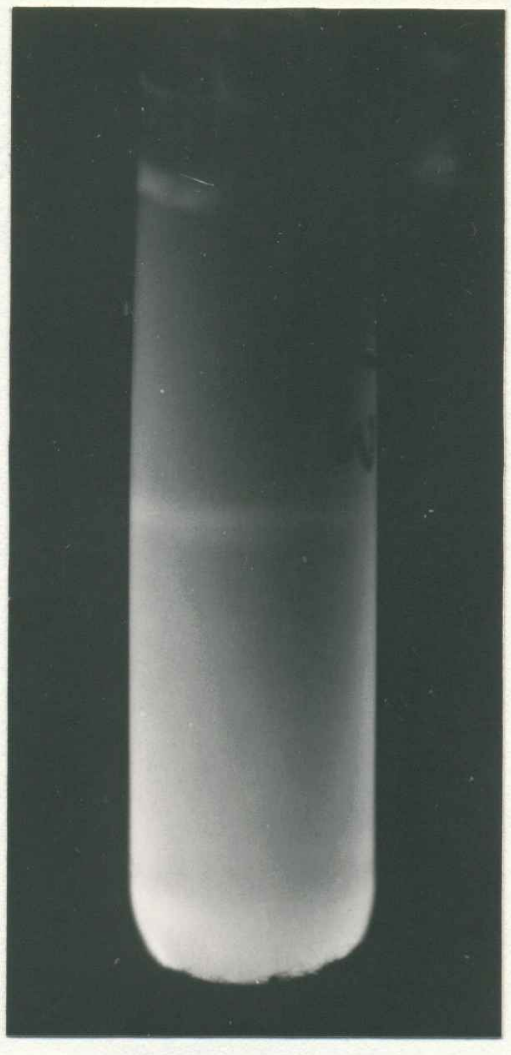

Figure 6 
Figure 7. CsCl-EtBr equilibrium centrifugation of an Mc. voltae lysate.

A $100 \mathrm{ml}$ culture of Mc. voltae was resuspended in $0.4 \mathrm{ml}, 2 \%$ TES buffer (Method IV). Two $\mathrm{ml}$ of $1 \%$ Sarkosyl in TE buffer was added to lyse the cells. The thick lysate was gently poured on top of 3.8 grams of $\mathrm{CsCl}$ dissolved in $2 \mathrm{ml}$ TE buffer in a $5.5 \mathrm{ml}$ polyalomer centrifuge tube. Four tenths of a $\mathrm{ml}$ of an $\mathrm{EtBr}$ solution $(10 \mathrm{mg} / \mathrm{ml})$ was added. Mixing by gentle inversion failed to combine the EtBr or the lysate with the $\mathrm{CsCl}$ solution. The details of centrifugation and photography are described in Materials and Methods. Poloroid Type $57 \mathrm{film}$ was exposed $0.5 \mathrm{sec}$. 


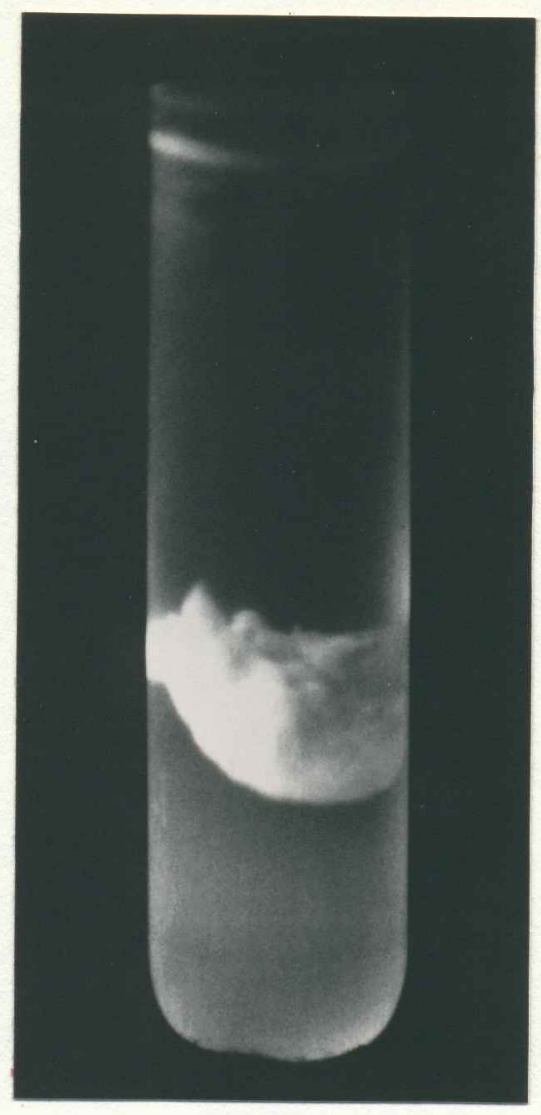

Figure 7 
Figure 8. CsCl-EtBr equilibrium centrifugation of Mc. voltae lysates prepared by heating.

Tube A contains E. coli 517 plasmid DNA isloated by Method V prior to equilibrium centrifugation. Tube B contains an Mc. voltae lysate prepared for equilibrium centrifugation as follows. A $200 \mathrm{ml}$ culture was resuspended in $2 \mathrm{~m} 1$ of $2 \%$ TES buffer (Method IV), and the bacteria were lysed in a $13 \mathrm{ml}$ polyalomer centrifuge tube, by the addition of $4 \mathrm{ml}$ of lysing solution (Method IV). The viscous lysate was placed in a $100^{\circ} \mathrm{C}$ water bath for 3 minutes which greatly reduced its viscosity, and then cooled 5 minutes on ice $\left(0^{\circ} \mathrm{C}\right)$. Six tenths of a ml of an $\mathrm{EtBr}$ solution $(10 \mathrm{mg} / \mathrm{ml})$ was added and then 6.0 grams of solid $\mathrm{CsCl}$ were dissolved into the lysate by gentle inversion. Tubes $A$ and $B$ were centrifuged in a $\mathrm{Ti} 50$ rotor. The Mc. voltae lysate in tube $\mathrm{C}$ was prepared from $25 \mathrm{ml}$ of culture resuspended in $0.5 \mathrm{ml}$ of $2 \%$ TES buffer (Method IV). Three $\mathrm{ml}$ of TE buffer and $0.3 \mathrm{ml}$ of Sarkosyl were added to lyse the cells in a $5.5 \mathrm{ml}$ polyalomer centrifuge tube. The viscous lysate was placed in a $100^{\circ} \mathrm{C}$ water bath for one minute and then cooled 5 minutes on ice $\left(0^{\circ} \mathrm{C}\right)$. Four tenths of a $\mathrm{ml}$ of an $\mathrm{EtBr}$ solution (10 $\mathrm{mg} / \mathrm{ml}$ ) was added and then 4.0 grams of solid $\mathrm{CsCl}$ were dissolved into the lysate by gentle inversion. Tube $C$ was centrifuged in a SW 65 rotor. 

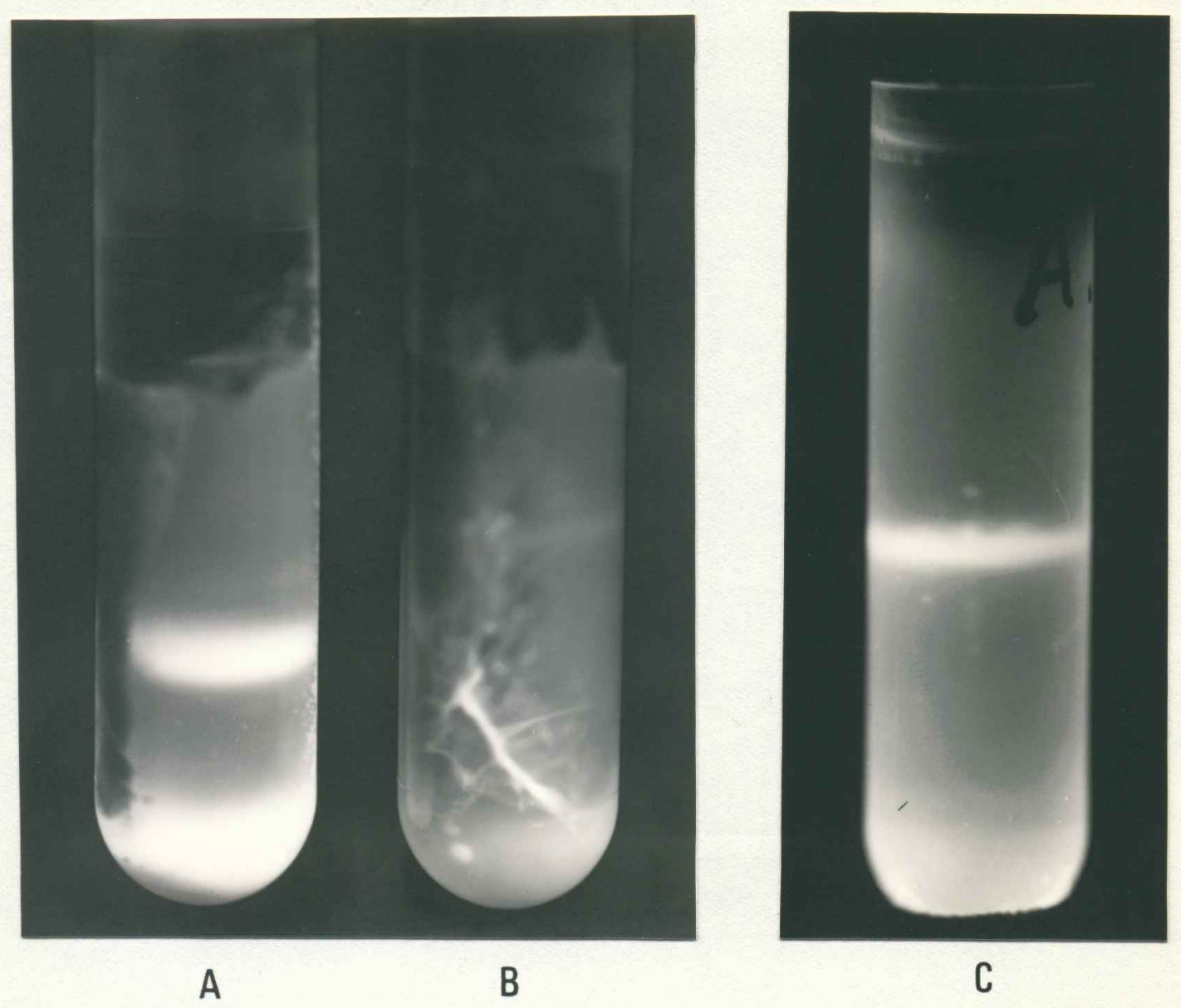

Figure 8 
E. coli linear DNA, the faint upper band in tube $A$ of Figure 8 . The concentrated lower band in tube $A$ was identified as plasmid DNA by electrophoretic analysis. Electrophoretic analysis of the DNA recovered from the band in tube $B$ (Figure 8 ), indicated that it was linear chromosomal DNA (see Figure 10, lane A).

The result of centrifugation of a lysate into which solid $\mathrm{CsCl}$ was dissolved by stirring is shown in figure 9. The DNA band was very viscous like the clots, and remained viscous even after removal of $\mathrm{CsCl}$ and EtBr. Electrophoretic analysis indicated the DNA of the viscous band was also linear chromosomal DNA (see Figure 10, lane C).

CsCl-EtBr equilibrium density centrifugation of Mc. voltae DNA prepared by Method $V$ resolved no DNA bands. As mentioned before, Method IV is extremely efficient at removing linear DNA. All fluorescence was concentrated at the bottom of the tube. Electrophoretic analysis of Mc. voltae DNA prepared by Method $V$ before equilibrium centrifugation indicated that only the trailing band survives potassium-acetate precipitation (data not shown).

\section{DETERMINATION OF THE CHARACTER OF THE DNA RESOLVED FROM Mc. voltae}

Relative Migration in Agarose Gels

It is possible to determine if DNAs resolved electrophoretically are of the same form (CCC, open circular, or linear) by comparing their mobilities at two different agarose concentrations. By virtue of their structures, each form migrates through an agarose matrix at a characteristic rate. In addition, the degree to which migration is 
Figure 9. CsCl-EtBr equilibrium centrifugation of an Mc. voltae lysate prepared by stirring.

A $25 \mathrm{ml}$ culture of Mc. voltae was resuspended in $0.5 \mathrm{ml}$ of $2 \%$ TES buffer (Method IV). Three $\mathrm{ml}$ of TE buffer and $0.3 \mathrm{ml}$ of Sarkosyl were added to lyse the cells in a $5.5 \mathrm{ml}$ polyalomer centrifuge tube. A homogeneous lysate was obtained after one gentle inversion of the tube. Four grams of solid $\mathrm{CsCl}$ were dissolved into the lysate by gentle stirring with a glass rod. Four tenths of a $\mathrm{ml}$ of an EtBr solution $(10 \mathrm{mg} / \mathrm{ml})$ was added and dispersed by gentle inversion. The details of centrifugation and photography are described in Materials and Methods. Polaroid Type 57 film was exposed 0.5 seconds. 


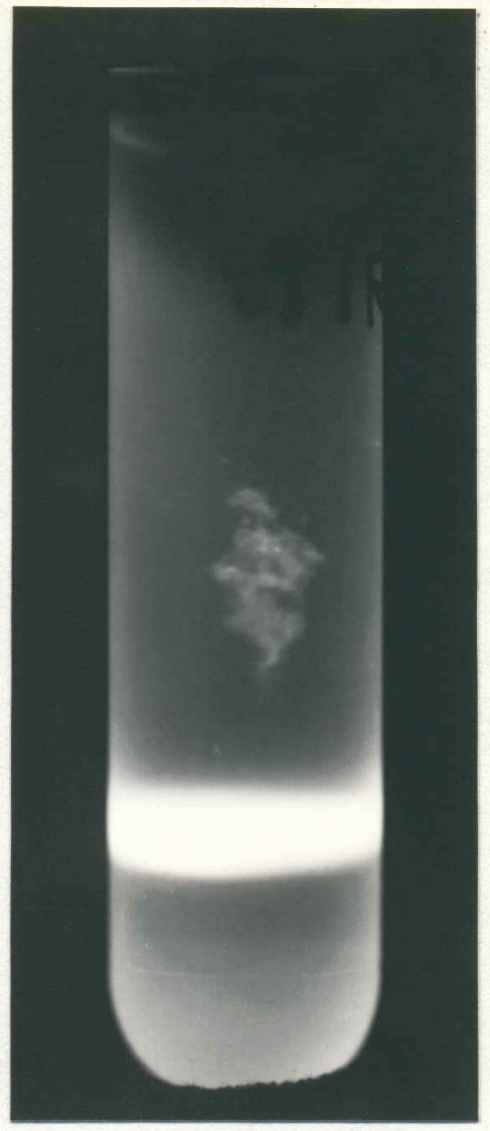

Figure 9 
Figure 10. Agarose gel electrophoresis of Mc. voltae DNA isolated by CsCl-EtBr equilibrium centrifugation.

The DNA in lane $A$ was recovered from tube $C$ of Figure 8 . Lane $B$ contains the DNA standard prepared from $\underline{E}$. coli 517 . The DNA in lane $C$ was recovered from the tube in Figure 9. Electrophoresis was for 4.5 hours at 100 volts. 


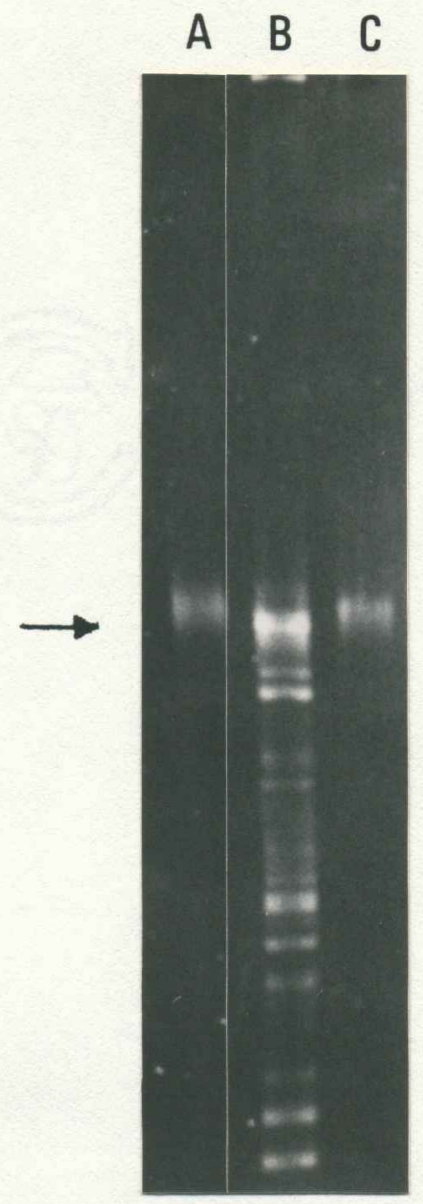

Figure 10 
retarded as agarose concentration is increased is also characteristic to each form. Therefore, if two DNAs were observed to migrate proportional distances (i.e. if they have the same relative mobility) in two different agarose concentrations, they are probably of the same form. Conversely, the migration of DNAs of two different forms will not be proportional at different agarose concentrations. The latter phenomenon is illustrated in Figure 11 (lane D, Gel I and Gel II). Migration of the various plasmid forms present in the E. coli 517 DNA sample, is not proportional to the migration of the chromosomal band at the two different agarose concentrations.

Methanococcus voltae DNA prepared as described in the legend of Figure 14 was subjected to electrophoresis in $0.7 \%$ and $1.2 \%$ agarose gels. In Figure 11, two diffuse bands were observed: one corresponding to chromosomal DNA and another of lesser mobility. The distance migrated by each band was measured from the leading edge of the gel slot to the leading edge of the DNA band in all these migration studies. From the electrophoretic results shown in Figure 11 , relative mobility (the ratio of the distance migrated by the trailing band over the distance migrated by the bottom band) is 0.8 for both gels. These results suggest that the two DNA bands are of the same form: linear DNA. Lysis and electrophoresis of E. coli R45 and Mc. voltae by the Eckhardt procedure was performed in $0.7 \%$ and and $1.2 \%$ agarose gels as shown in Figure 12. A single band is resolved from the Mc. voltae lysates. To determine whether this band was Mc. voltae chromosomal DNA or the plasmid-like band observed trailing the chromosomal band in the Eckhardt results shown in Figure 5 (lanes $A$ through $D$ ), the mobility of this single band was compared to the mobilities of the bands in 
Figure 11 . Comparative migration in $1.2 \%$ and $0.7 \%$ agarose of DNA isolated from Mc. voltae.

Gel I was $1.2 \%$ agarose. Gel II was $0.7 \%$ agarose. Identical samples were applied to both gels. Lanes A, B and C contain the same Mc. voltae DNA samples, respectively, as lanes C, D and E of Figure 13. Lane D contains the DNA standard prepared from E. coli 517. Electrophoresis of both gels was for 5 hours at 100 volts. 


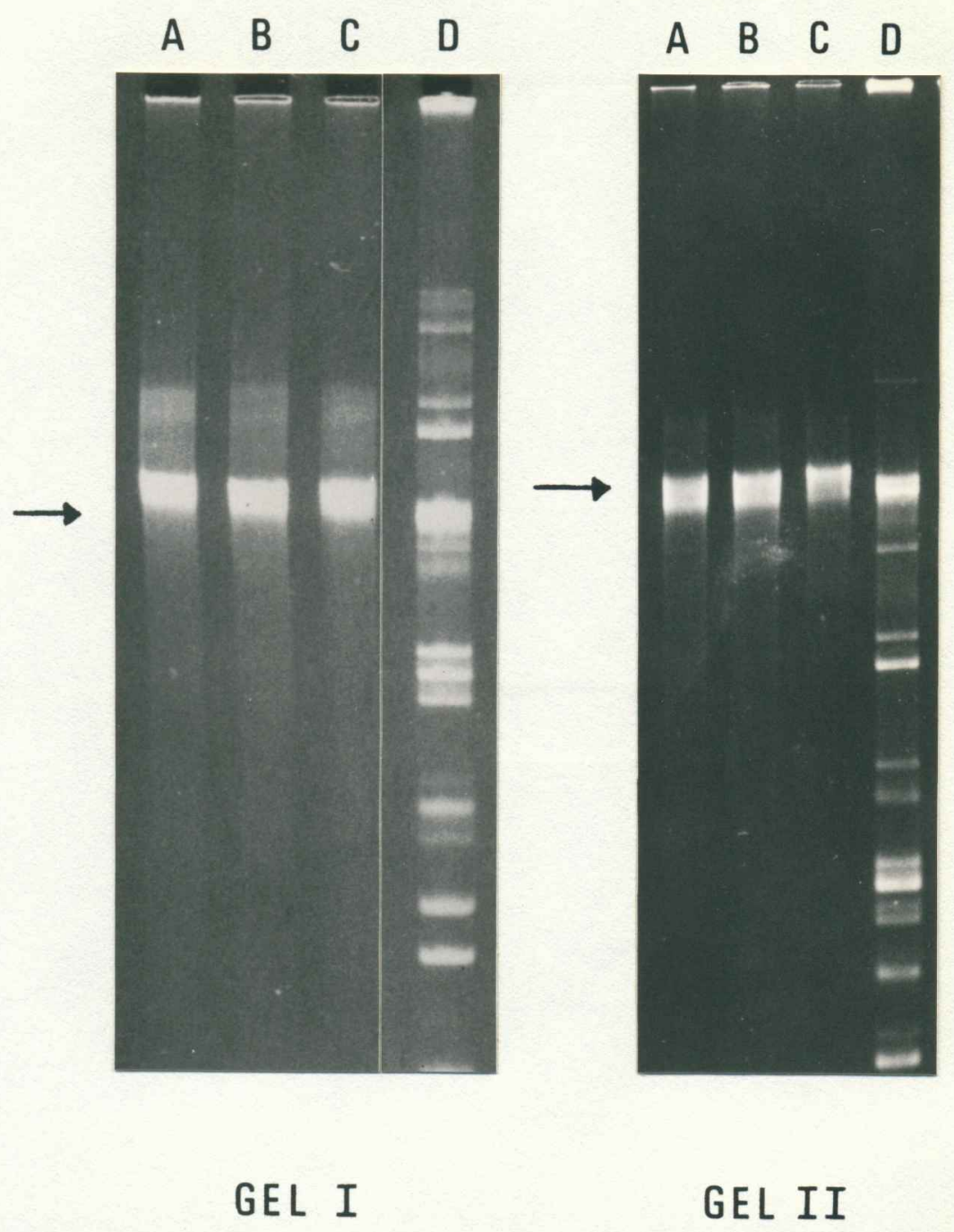

Figure 11 
Figure 12. Comparative migration in $1.2 \%$ and $0.7 \%$ agarose gels of DNA from Mc. voltae lysates.

Gel I was $1.2 \%$ agarose. Gel II was $0.7 \%$ agarose. Identical samples were applied to both gels. Lanes A, B and C contained $0.3 \mathrm{ml}$, $0.4 \mathrm{ml}$ and $0.5 \mathrm{ml}$ of $\underline{M c}$. voltae culture, respectively. Lanes $D$ and $E$ contained $.05 \mathrm{ml}$ and $0.1 \mathrm{ml}$ of $\underline{E}$. coli 517 culture, respectively. Lanes $F$ and $G$ contained $.05 \mathrm{ml}$ and $0.1 \mathrm{ml}$ of $\underline{E}$. coli R45 culture, respectively. Electrophoresis was for one hour at 25 volts and then seven hours at 130 volts. 


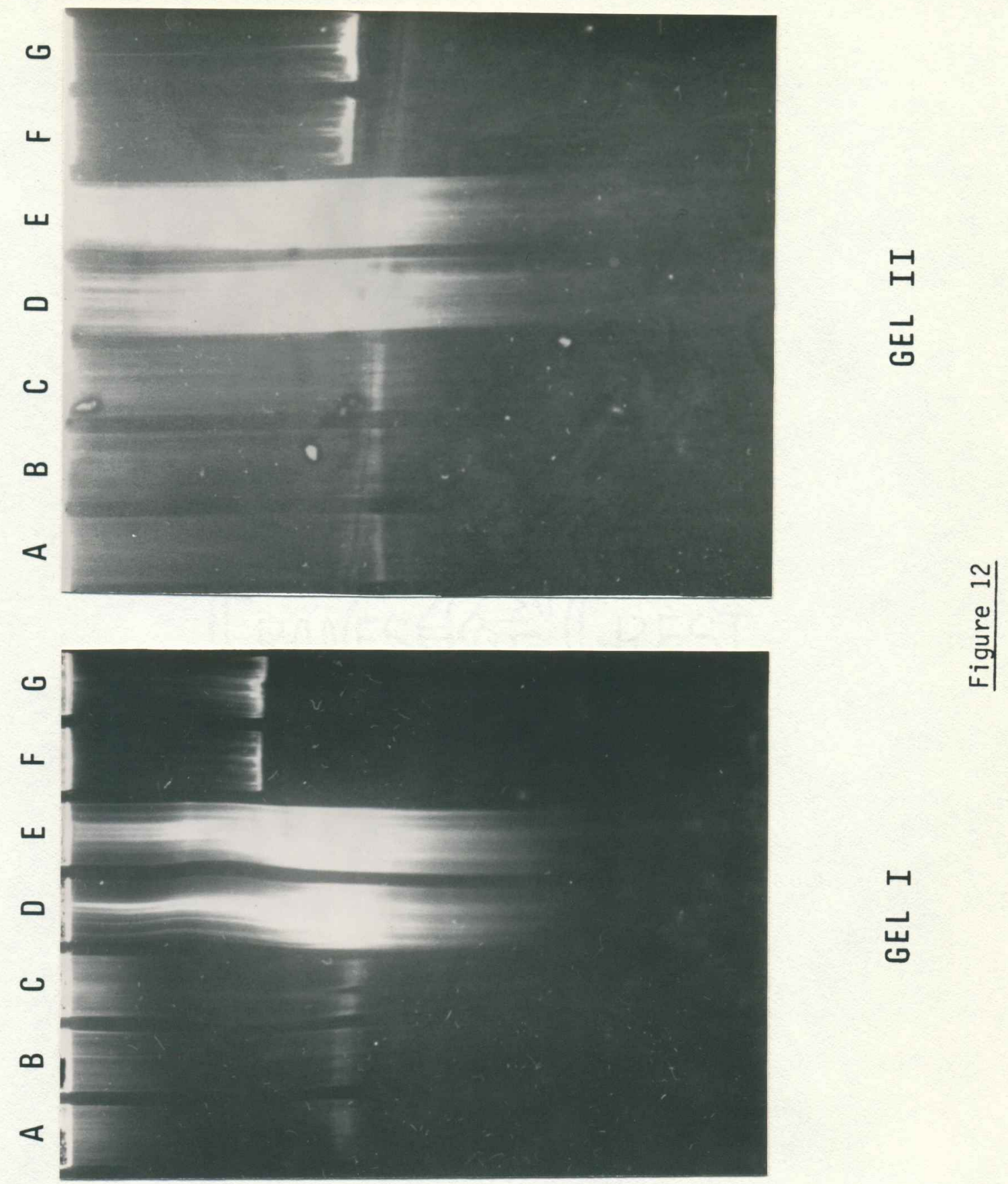


Figure 5. In Figure 12, in $0.7 \%$ agarose, the ratio of the distance migrated by the Mc. voltae band over the distance migrated by the R45 plasmid corresponds to the relative mobility of the plasmid-like band in the $0.8 \%$ agarose gel shown in Figure 5 . This correspondence indicates that the Mc. voltae band observed in the $0.7 \%$ gel is the trailing plasmid-like band, not chromosomal DNA. The single band observed in the $1.2 \%$ agarose gel (Figure 12) is assumed to be the same. Figure 12 shows that the mobility of the single Mc. voltae band relative to the mobility of the R45 plasmid is not the same at the two different agarose concentrations: 0.68 for the $1.2 \%$ gel and 0.93 for the $0.7 \%$ gel. These results indicate that the DNA band from Mc. voltae which looks so much like a plasmid band, does not contain CCC, plasmid DNA.

Test for Nuclease Activity in Mc. voltae Lysates

To determine the extent of plasmid degradation, including the conversion of CCC DNA to open circular form, due to nuclease activity in lysates of Mc. voltae, E. coli 517 plasmid DNA was isolated in the presence of an Mc. voltae lysate. Equal volumes of the two bacterial cultures were combined and pelleted for plasmid isolation by Method IV. As shown in Figure 13, lane A, the eight plasmids of $\underline{E}$. coli 517 were clearly resolved: nuclease degradation appears insignificant. The two faint bands observed migrating just ahead of the chromosomal band are probably open circular (nicked) plasmid molecules; however, these are extremely minor components of the plasmid preparation. The diffuse band trailing the chromosomal band is assumed to be derived from Mc. voltae. The migration of this band corresponds to that of the diffuse band observed in the Mc. voltae DNA preparation in lane C. The results 
Figure 13. Agarose gel electrophoresis of plasmid DNA isolated

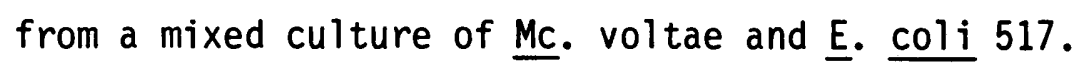

The DNA in lane A was prepared from equal volumes of Mc. voltae and E. coli 517 cultrues. The cells were pelleted and resuspended for immediate isolation of plasmid DNA by Method IV. Lane B contains the DNA standard prepared from E. coli 517 . The DNA in lane $C$ was prepared from Mc. voltae by Method IV. Electrophoresis was for 4.5 hours at 100 volts. 


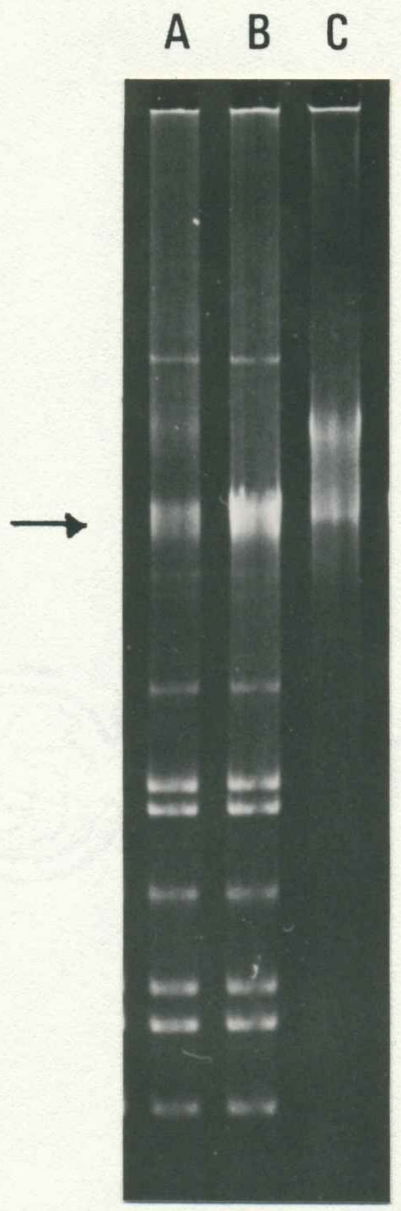

Figure 13 
suggest that the failure to isolate plasmids from Mc. voltae is not due to excessive nuclease activity in the lysates.

The Effect of Alkaline Denaturation

The alkalinity of Method IV preparations of Mc. voltae DNA was experimentally controlled to determine if alkaline denaturation affected the concentrations of the DNAs resolved. For this experiment cells were lysed with a neutral lysing solution and $2 \mathrm{~N} \mathrm{NaOH}$ was added to raise the $\mathrm{pH}$ of individual lysates. The viscosity of the lysates made gentle dispersion of added $\mathrm{NaOH}$ difficult and, therefore, the $\mathrm{pH}$ of the lysates may not have been uniform. The amount of $\mathrm{NaOH}$ added increases from left to right in Figure 14. The apparent chromosomal band from Mc. voltae is diminished with increasing alkalinity, lanes $A$ and $B$. This elimination of chromosomal DNA contrasts with an increase in the intensity, at high alkalinity, of the trailing band. The change in concentrations of the two bands appears inversely proportional. When Mc. voltae DNA was prepared without alkaline denaturation entirely, the trailing chromosomal band is not resolved as shown in Figure 15, lane $\mathrm{C}$. The trailing chromosomal band is present in lanes B and D which contain Mc. voltae DNA prepared with an alkaline denaturation, for comparison.

Tests for the Presence of Protein in the Trailing Band from Mc. voltae.

DNA prepared from Mc. voltae by Method IV was analyzed spectrophotometrically. An absorbance peak at $280 \mathrm{~nm}$ was not detected indicating the absence of proteins which contain aromatic amino acids.

DNA prepared from Mc. voltae by Method V was treated with protease $(20 \mathrm{mg} / \mathrm{ml})$ for the removal of protein. Following incubation at $37^{\circ} \mathrm{C}$ for 
Figure 14. The effect of alkalinity.

Methanococcus voltae DNA was prepared as described for Method IV with the following modifications. DNA samples applied to lanes A through $\mathrm{E}$ were prepared from $25 \mathrm{ml}$ cultures resuspended in $1 \mathrm{ml}$ of $2 \%$ TES buffer (Method IV). The pH of the lysing solution was 11.0. The pH of the lysates were raised by the addition of $12 \% \mathrm{NaOH}$ as follows: lane A, $260 \mu 1$; lane $B, 200 \mu 1$; lane $C, 120 \mu 1$; lane $D, 100 \mu 1$; lane $E, 60$ $\mu 1$. The lysates were held at high $\mathrm{pH}$ for approximately 2 minutes each and were then neutralized. Lane $F$ contains the DNA standard prepared from E. coli 517. Electrophoresis was performed in $1.2 \%$ agarose at 100 volts for 5 hours. 


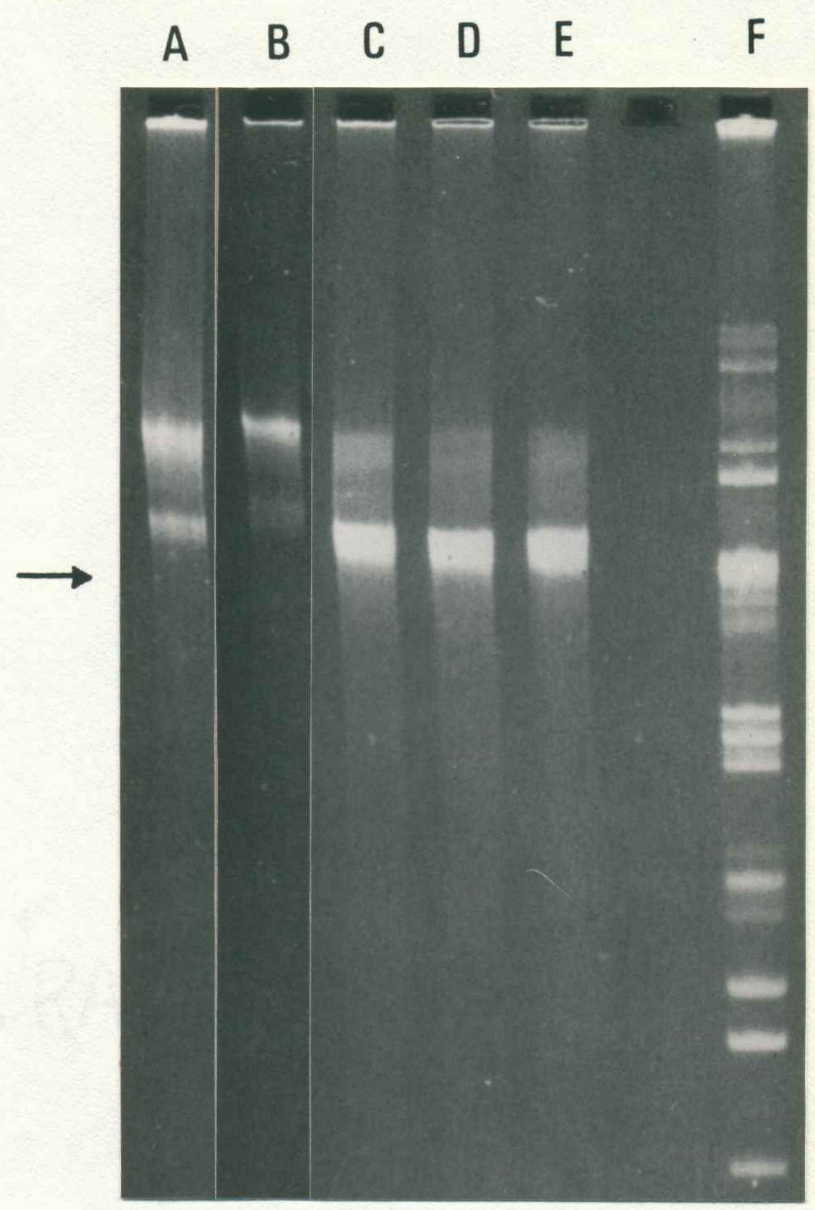

Figure 14 
Figure 15. Agarose gel electrophoresis of Mc. voltae DNA prepared with and without alkaline denaturation.

Lane A contains the DNA standard prepared from E. coli 517. Mc. voltae DNA was prepared from $20 \mathrm{ml}$ cultures as described for Method IV with the following modifications. The cells were resuspended in $25 \%$ sucrose $(1 \mathrm{ml})$. The $\mathrm{pH}$ of the lysing solution was 9.0. DNA samples in lanes $B$ and $D$ were prepared with alkaline denaturation. The $\mathrm{pH}$ of the lysates were raised by the addition of $150 \mu 1$ of $12 \% \mathrm{NaOH}$. These lysates were held at high $\mathrm{pH}$ on ice for 5 minutes and were then neutralized. The DNA sample in lane $C$ was prepared without alkaline denaturation. No $\mathrm{NaOH}$ was added. Electrophoresis was performed at 100 volts for 4 hours. 


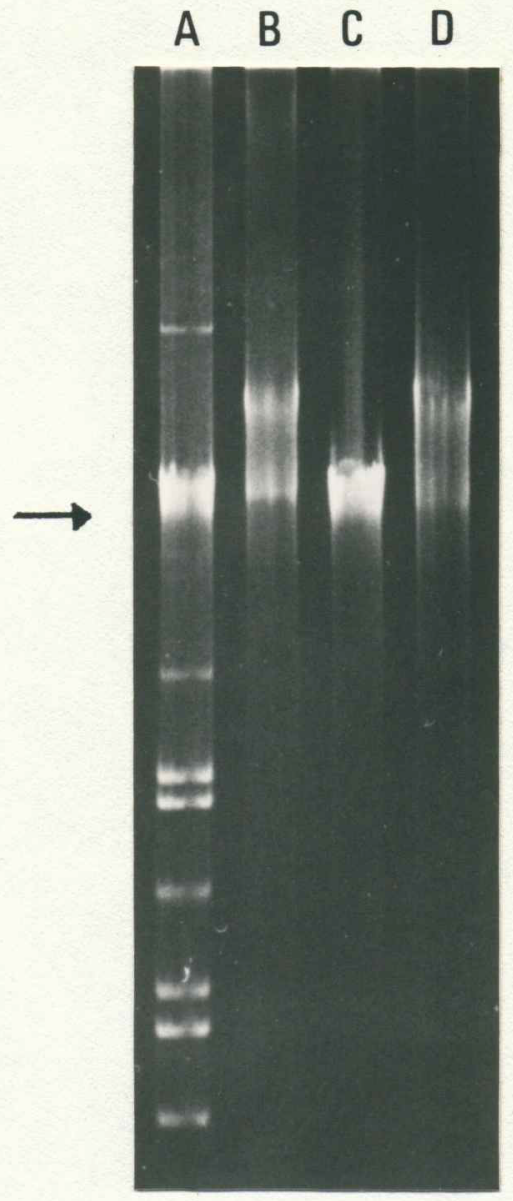

Figure 15 
30 minutes, the DNA sample was analyzed by agarose gel electrophoresis. The same diffuse band, migrating slower than the chromosomal DNA standard, was resolved from both protease treated and untreated DNA samples. The protease treatment had no detectable effect on the DNA of the diffuse band.

\section{The Effect of Phenol Extraction}

DNA bands resolved from $\underline{M}$. thermoautotrophicum by an alkaline denatured preparation which includes phenol extraction differ from those prepared by methods which do not call for extraction with phenol (compare the results of Figures 1 and 2 ). To determine the effect of phenol extraction on the DNA bands resolved from Mc. voltae, a phenol-chloroform extraction was included in Method IV. With and without alkaline denaturation, only one intense chromosomal band was resolved after extraction with phenol (data not shown). 


\section{DISCUSSION}

The plasmid isolation and detection techniques selected for use in this study have resolved plasmids, 2 to $400 \mathrm{Md}$ in size, from a wide variety of gram positive and gram negative bacteria. Using these techniques, plasmid DNA was not recovered from any of the methanogens.

While electrophoretic analysis of DNA isolated from Ms. hungatii resolved only linear chromosomal DNA, clearly indicating the absence of any extra chromosomal elements, analysis of isolated DNAs from the other methanogens tested were not as conclusive. A distinct diffuse band resembling linear chromosomal DNA, but having a lower mobility, was seen after electrophoresis of DNA samples prepared by alkaline extraction from M. thermoautotrophicum, Mb. arboriphilus, Methanobrevibacter sp. and Mc. voltae. This band was most distinct in the preparations of DNA from Mc. voltae. The band appeared sharp (almost plasmid-like) in some of the Mc. voltae preparations, the concentration of the band varied, and on occasion it appeared alone without a chromosomal band although in most preparations at least a faint chromosomal band was observed. A distinct plasmid-like band, migrating just behind chromosomal DNA was observed when Mc. voltae DNA was analyzed electrophoretically by the Eckhardt method.

A study of the mobility of the trailing band, resolved from Mc. voltae by alkaline extraction, relative to the mobilities of CCC plasmid DNA and linear chromosomal DNA, in two different agarose gel 
concentrations, revealed that the band did not contain CCC DNA: the relative mobility of the band corresponded to linear chromosomal DNA. The relative mobility of the trailing band observed in the Eckhardt preparations also did not correspond to the mobility of CCC DNA; however, the possibility that this band is the open circular form of a plasmid cannot be eliminated on the basis of these results. Open circular forms of plasmids are usually generated by nuclease nicking of one strand of a circular DNA molecule. If the band observed in the Mc. voltae preparations was the open circular form of a plasmid, extremely active nucleases would have to be present in the Mc. voltae lysate to nick almost every CCC DNA molecule. Plasmids of E. coli 517 isolated in the presence of an Mc. voltae lysate were not converted to open circular molecules, indicating that nuclease activity in the methanogen lysate was insignificant. A plasmid, if present in Mc. voltae, would be expected to survive the isolation procedure also.

These observations, and the fact that all attempts to isolate CCC DNA from the methanogens by CsCl-EtBr equilibrium density gradient centrifugation were unsuccessfur, are strong indications that plasmids of $100 \mathrm{Md}$ and less do not exist in these methanogenic strains. It is possible that the high molecular weight plasmid-like band, resolved from Mc. voltae by the Eckhardt procedure, consisted of plasmid DNA 500 Md or greater in size. The plasmid could have been lost by repeated subculture of Mc. voltae and was, therefore, not observed in later Eckhardt preparations. It has been suggested, however, that this band may have been the entire Mc. voltae chromosome which has been determined to be approximately $1000 \mathrm{Md}$ in size (9). In the later Eckhardt preparations, the Mc. voltae lysates were not stirred in the wells of 
the agarose gels as they were in the earlier preparations. Stirring may have released the intact chromosome from the bacterial membrane, freeing it for electrophoretic migration into the agarose gel.

Having established that the DNA band resolved from Mc. voltae was not plasmid DNA, the molecular character of the band was investigated. Despite the fact that the trailing band component of DNA prepared by alkaline extraction has a mobility in agarose similar to linear chromosomal DNA, the band cannot be linear double stranded DNA. The mobility of linear DNA becomes insensitive to molecular weight at approximately $14 \mathrm{Md}$ in $0.8 \%$ agarose and $15 \mathrm{Md}$ in $0.7 \%$ agarose (21). Diffuse chromosomal bands include all linear DNA of this size and greater. No linear DNA, regardless of its molecular weight, should appear to migrate slower than chromosomal DNA.

One explanation for the retarded migration of double stranded DNA is that the DNA might be associated with protein in such a way that the charge on the DNA molecule is partially neutralized. If the protein were removed, the linear double stranded DNA would then migrate to the chromosomal position. In fact, when Mc. voltae DNA was prepared by extraction with phenol, a strong protein denaturant, the trailing band was not observed: only a chromosomal band was seen. These results, which suggest that protein may be associated with the Mc. voltae DNA, appear to conflict with the following observations. DNA prepared from Mc. voltae was analyzed spectrophotometrically. An absorbance peak was not detected at $280 \mathrm{~nm}$, indicating the absence of protein in the DNA sample. A protein detection method not based upon the presence of aromatic amino acids was not performed. Treatment of the DNA with protease did not alter its banding character; the trailing band was not 
converted to a typical chromosomal DNA band. The phenol extraction step, included in some plasmid isolation techniques, selectively precipitates single stranded DNA (25). The elimination of the trailing band by phenol treatment lends support to the idea, discussed below, that the band consists of single stranded DNA.

Another explanation of the character of the trailing band is that the band represents high molecular weight RNA. The following observation excludes this explanation: the appearance of the trailing band is dependent upon the alkaline denaturation step which is designed to remove alkaline sensitive RNA (RNA is quickly degraded at $\mathrm{pH} 12$ ). The trailing band was not observed when Mc. voltae DNA was prepared without alkaline denaturation.

Although the trailing band is a product of alkaline denaturation, it is probably not denatured linear DNA because single stranded linear DNA is reported to migrate faster in agarose than double stranded DNA of corresponding size (17). If, upon neutralization, a single stranded DNA molecule were to renature with itself, a hairpin molecular form could result. These part single stranded, part double stranded molecules might show retarded mobility in agarose. Such intramolecular renaturation can only occur if the single stranded DNA fragments contain inverted repeated sequences. Renaturation studies have revealed that $6 \%$ of the genome of $\underline{M}$. thermoautotrophicum is renatured at zero-time and may contain highly repetitive DNA (9), which are probably inverted repeated sequences. The electrophoretic banding pattern observed in this study may be an indication that the genomes of Mc. voltae, Mb. arboriphilus and Methanobrevibacter sp. also contain significant amounts of highly repetitive DNA. Since this banding was not seen with any DNA 
samples prepared from Ms. hungatii, the genome of this organism may differ significantly in character from the other methanogens used in this study. 


\section{REFERENCES CITED}

(1) Woese, C. R. 1981. Archaebacteria. Scientific American Vol. 244, June: $98-122$.

(2) Balch, W., L. Magrum, G. Fox, R. Wolfe, and C. R. Woese. 1977. An Acient Divergence Among the Bacteria. Journal of Molecular Evolution 9:305-311.

(3) Fox, G., L. Magrum, W. Balch, R. Wolfe, and C. R. Woese. 1977. Classification of Methanogenic Bacteria by Ibs Ribosomal RNA Characterization. Proceedings of the National Academy of Sciences 74:4537-4541.

(4) Balch, W., G. Fox, L. Magrum, C. R. Woese, and R. Wolfe. 1979. Methanogens: Reevaluation of a Unique Biological Group. Microbiological Reviews. 43:260-296.

(5) Woese, C., L. Magrum, and G. Fox. 1978. Archaebacteria. Journal of Molecular Evolution 11:245-252.

(6) Stetter, K. 0., J. Winter, and R. Hartlieb. 1980. Zbl. Bakt. Hyg. I. Abt. Orig. C 1, 201-214.

(7) Best, A. N. 1978. Composition and Characterization of tRNA from Methanococcus vannielii. Journal of Bacteriology 133:240-250.

(8) Thomm, Michael, K. 0. Stetter, and W. Zillig. 1982. Histone-like Proteins in Eu and Archaebacteria. Zbl. Bakt. Hyg., I. Abt. Orig. C 3, 128-139.

(9) Mitchell, R., L. Loeblich, L. Kotz, and A. Loeblich III. 1978. Organization of Methanobacterium thermoautotrophicum. Science 204:1082-184.

(10) Moore. Characterization of the Deoxyribomicleic Acid of Various Strains of Halophilic Bacteria. Journal of Bacteriology. 99:249-254.

(11) Pfeifer, Felicitas. Structure and Function of Chromosomal and Extrachromosomal DNA in Halobacterium. Zbl. Bakt. Hyg. I. Abt. Orig. C 3:110.

(12) Aranki, A. and R. Freter. 1972. Use of Anaerobic Glove Boxes for the Cultivation of Strictly Anaerobic Bacteria. American Journal of Clinical Nutrition. 25:1329-1334. 
(13) Kado, C. I. and S. T. Liu. 1981. Rapid Procedure for Detection and Isolation of Large and Small Plasmids. Journal of Bacteriology. 145:1365-1373.

(14) Casse, Francine, C. Boucher, J. S. Julliot, M. Michel, and J. Denarie. 1979. Identification and Characterization of Large Plasmids in Rhizobium meliloti using Agarose Gel Electrophoresis. Journal of General Microbiotogy. 113:229-242.

(15) Hansen, Jeffrey B. and Ronald H. 01 sen. 1978. Isolation of Large Bacterial Plasmids and Characterization of the P2 Incompatability Group Plasmids pMG1 and PMG5. Journal of Bacteriology. 135:227-238.

(16) Birnboim, H. C. and J. Doly. 1979. A Rapid Alkaline Extraction Procedure for Screening Recombinant Plasmid DNA. Nucleic Acids Research. 2:1513-1523.

(17) Maniatis, T. Molecular Cloning: A Laboratory Manual. New York: Cold Spring Harbor Laboratory, 1982.

(18) Rosenberg, Charles, F. Casse-Delbart, I. Dusha, M. David, C. Boncher. 1982. Megaplasmids in the Plant-associated Bacterium Rhizobium meliloti and Pseudomonas solanacearum. Journal of BacterioTogy. 150:402-406.

(19) Eckhardt, Thomas. 1978. A Rapid Method for the Identification of Plasmid Desoxyribonucleic Acid in Bacteria. Plasmid. 1:584-588.

(20) Pouwe1s, P. H., J. van Rotterdam and J. A. Cohen. 1969. Structure of the Replicative Form of Bacteriophage $6 \times 174$. Journal of Molecular Biology. 40:379-390.

(21) Mickel, Susan, A. Vincent, and W. Bauer. 1977. Physical Properties and Gel Electrophoresis Behavior of R12-derived Plasmid DNAs. Nucleic Acids Research. 4:1465-1482.

(22) Crosa, Jorge H., Stanley Falkow. Manual of Methods for General Bacteriology. Washington, D.C.: American Society for Microbiology, 1981. Chapter 15, p. 268.

(23) Kandler, Otto and Helmut Konig. 1978. Chemical Composition of the Peptidoglycan-free Cell Walls of Methanogenic Bacteria. Archives of Microbiology 118:141-152.

(24) Sprott, G. D. and R. C. McKellar. 1979. Composition and Properties of the Cell Wall of Methanospirillum hungatii. Canadian Journal of Microbiology 26:115-120.

(25) Currier, T. C., and E. W. Nester. 1976. Isolation of Covalently Closed Circular DNA of High Molecular Weight from Bacteria. Analytical Biochemistry 76:431-441. 